\title{
The Fate of Carbon in Sediments of the Xingu and Tapajós Clearwater Rivers, Eastern Amazon
}

\author{
Dailson J. Bertassoli Jr. ${ }^{1 *}$, André O. Sawakuchi ${ }^{1}$, Henrique O. Sawakuchi ${ }^{2}$, \\ Fabiano N. Pupim ${ }^{1}$, Gelvam A. Hartmann ${ }^{3}$, Michael M. McGlue ${ }^{4}$, Cristiano M. Chiessi ${ }^{5}$, \\ Matthias Zabel ${ }^{6}$, Enno Schefuß ${ }^{6}$, Tatiana S. Pereira ${ }^{7}$, Rudney A. Santos ${ }^{1}$, \\ Samantha B. Faustino ${ }^{8}$, Paulo E. Oliveira ${ }^{1}$ and Denise C. Bicudo ${ }^{8}$ \\ ${ }^{1}$ Institute of Geosciences, University of São Paulo, São Paulo, Brazil, ${ }^{2}$ Environmental Analysis and Geoprocessing \\ Laboratory, Center for Nuclear Energy in Agriculture, University of São Paulo, Piracicaba, Brazil, ${ }^{3}$ Instituto de Geociências, \\ Universidade Estadual de Campinas, Campinas, Brazil, ${ }^{4}$ Department of Earth and Environmental Sciences, University of \\ Kentucky, Lexington, KY, USA, ${ }^{5}$ School of Arts, Sciences and Humanities, University of São Paulo, São Paulo, Brazil, \\ ${ }^{6}$ MARUM-Center for Marine Environmental Sciences, University of Bremen, Bremen, Germany, ${ }^{7}$ Federal University of Pará, \\ Campus de Altamira, Altamira, Brazil, ${ }^{8}$ Department of Ecology, Instituto de Botânica, São Paulo, Brazil
}

The Xingu and Tapajós rivers in the eastern Amazon are the largest clearwater systems

OPEN ACCESS

Edited by:

Carol Robinson,

University of East Anglia, UK

Reviewed by:

Michael Gonsior

University of Maryland Center For

Environmental Sciences, USA

Armstrong-Altrin John S.,

National Autonomous University of

Mexico, Mexico

*Correspondence:

Dailson J. Bertassoli Jr. dailson.bertassoli@gmail.com

Specialty section:

This article was submitted to Marine Biogeochemistry,

a section of the journal

Frontiers in Marine Science

Received: 07 November 2016 Accepted: 07 February 2017

Published: 22 February 2017

Citation:

Bertassoli DJ Jr., Sawakuchi AO, Sawakuchi HO, Pupim FN, Hartmann GA, McGlue MM, Chiessi CM, Zabel M, Schefuß E, Pereira TS,

Santos RA, Faustino SB and Oliveira PE and Bicudo DC (2017) The

Fate of Carbon in Sediments of the Xingu and Tapajós Clearwater Rivers, Eastern Amazon.

Front. Mar. Sci. 4:44.

doi: 10.3389/fmars.2017.00044 of the Amazon basin. Both rivers have "fluvial rias" (i.e., lake-like channels) in their downstream reaches as they are naturally impounded by the Amazon mainstem. Fluvial rias are widespread in the Amazon landscape and most of the sedimentary load from the major clearwater and blackwater rivers is deposited in these channels. So far, little is known about the role of Amazon rias as a trap and reactor for organic sediments. In this study, we used organic and inorganic geochemistry, magnetic susceptibility, diatom, and pollen analyses in sediments (suspended, riverbed, and downcore) of the Xingu and Tapajós rias to investigate the effects of hydrologic variations on the carbon budget in these clearwater rivers over the Holocene. Ages of sediment deposition ( 100 to 5,500 years) were constrained by optically stimulated luminescence and radiocarbon. Major elements geochemistry and concentration of total organic carbon (TOC) indicate that seasonal hydrologic variations exert a strong influence on riverine productivity and on the input and preservation of organic matter in sediments. Stable carbon isotope data $\left(\delta^{13} \mathrm{C}\right.$ from -31.04 to $\left.-27.49 \%\right)$ and pollen analysis indicate that most of the carbon buried in rias is derived from forests. In the Xingu River, diatom analysis in bottom sediments revealed 65 infrageneric taxa that are mostly well-adapted to slack oligotrophic and acidic waters. TOC values in sediment cores are similar to values measured in riverbed sediments and indicate suitable conditions for organic matter preservation in sediments of the Xingu and Tapajós rias at least since the mid-Holocene, with carbon burial rates varying from about $84 \mathrm{~g} \mathrm{~m}^{-2} \mathrm{yr}^{-1}$ to $169 \mathrm{~g} \mathrm{~m}^{-2} \mathrm{yr}^{-1}$. However, redox-sensitive elements in sediment core indicate alternation between anoxic/dysoxic and oxic conditions in the water-sediment interface that may be linked to abrupt changes in precipitation. The variation between anoxic/dysoxic and oxic conditions in the water-sediment interface controls organic matter mineralization and methanogenesis. Thus, such changes promoted by hydrological variations significantly affect the capacity of Amazon rias to act either as sources or sinks of carbon.

Keywords: Amazon, Carbon Cycle, Xingu River, Tapajós River, greenhouse gases 


\section{INTRODUCTION}

Recent research has undermined the view of rivers as passive conveyors of organic matter, and demonstrates their role in the transport, modulation, and deposition of carbon (Cole et al., 2007; Tranvik et al., 2009; Aufdenkampe et al., 2011; Ward et al., 2015). Inland waters emit at least $0.8 \mathrm{Pg}$ of carbon per year (Cole et al., 2007; Tranvik et al., 2009). Approximately one fourth of it comes from rivers (Cole et al., 2007). The Amazonian rivers represent about $15 \%$ of the terrestrial gross primary production and $25 \%$ of the global rivers emissions of $\mathrm{CO}_{2}$ (Field, 1998; Richey et al., 2002). Most studies that have considered organic matter remineralization and carbon storage in the region focused on the Amazon mainstem and its floodplains (Richey et al., 2002; Bouchez et al., 2010, 2012; Abril et al., 2014; Ward et al., 2015). However, the lack of geochemical data to constrain the role of major clearwater tributaries of the Amazon River as a source or sink of organic sediments limited the understanding of the carbon cycling dynamics across the terrestrial and aquatic environments of the Amazon basin.

The Xingu and Tapajós rivers represent the largest Amazon clearwater rivers, with mean annual discharges of 9,700 and $13,500 \mathrm{~m}^{3} \mathrm{~s}^{-1}$ (Latrubesse et al., 2005), respectively. They drain crystalline and sedimentary rocks of the Central Brazil shield and are characterized by relatively low concentrations of suspended sediments, slightly alkaline waters (Sioli, 1984), and high fluxes of methane to the atmosphere (Sawakuchi et al., 2014). Both rivers are naturally impounded by the Amazon mainstem, which give rise to broad downstream lake-like channels known as "fluvial rias" (Gourou, 1949; Archer, 2005). The Xingu and Tapajós rivers have strong seasonal variations, with mean monthly water discharges varying from approximately 1,000 to $20,000 \mathrm{~m}^{-3} \mathrm{~s}^{-1}$ in the Xingu River and 4,000 to $30,000 \mathrm{~m}^{-3} \mathrm{~s}^{-1}$ in the Tapajós River (ANA, 2016). The peak discharges of these clearwater rivers occurs from February to May. The Amazon River, however, has a mean monthly water discharge that varies from approximately $105,000 \mathrm{~m}^{-3} \mathrm{~s}^{-1}$ to $235,000 \mathrm{~m}^{-3} \mathrm{~s}^{-1}$, with peak discharge from April to July (ANA, 2016). The lag between the peak discharge of the Amazon River and its clearwater tributaries is responsible for strong backwater effects in the Xingu and Tapajós rivers (Meade et al., 1991). The sudden drop in water flow velocity and channel widening related to the hydraulic blockage and backwater effect by the Amazon mainstem prevent most of the Xingu and Tapajós suspended and bedload sediments from entering the Amazon River. These conditions turn rias into massive sinks for organic and inorganic sediments and natural reactors for carbon derived from the headwaters. Fluvial rias in the downstream section of the Xingu and Tapajós rivers reach up to $15 \mathrm{~km}$ width and around $150 \mathrm{~km}$ length. Hundreds of rias and paleo-rias occupy the Amazonian landscape and connect all clearwater and blackwater tributaries to the Amazon River, playing an important role for the transport and deposition of fine-grained sediments in the Amazon fluvial system. Thus, the accumulation of fine-grained sediments in rias has a strong effect on carbon processing and transport to the Amazon River and the Atlantic Ocean. To date, studies addressing Amazonian fluvial rias focus mainly on climatic and sediment deposition changes, without consensus about their genesis (Sioli, 1984; Keim et al., 1999; Vital and Stattegger, 2000; Bertani et al., 2014). The extant Amazon rias appear to have been formed after the Last Glacial Maximum (LGM, 23-19 ka) (Archer, 2005; Irion et al., 2011). The prevailing hypothesis suggests that the incised valleys formed during the low sea level phase of the LGM were flooded and accumulated sediments during the Holocene transgression (Archer, 2005; Irion et al., 2006, 2011). Sediment cores retrieved from the Tapajós Ria contain fine-grained sediments with $2.2-3.5 \%$ of total organic carbon and sedimentation rates reaching up to $6.5 \mathrm{~mm}$ $\mathrm{yr}^{-1}$ (Irion et al., 2006). This reinforces the potential of rias as location of sediment deposition and carbon processing in the Amazon fluvial system.

Rias show sedimentary dynamics similar to that of lakes and reservoirs, which bury more than $200 \mathrm{Tg}$ of organic carbon annually (Dean and Gorham, 1998). Despite the widespread distribution in the Amazon and dominance of organic-rich sediments (Irion et al., 2011), rias are poorly studied with respect to their role as sink or source of carbon in the Amazon basin. According to Sawakuchi et al. (2014), methane fluxes in Amazon rivers account for $22-28 \%$ of the global river emissions of methane and the Amazon rias are hotspots of methane production. Rias also serve as analogs for carbon processing in artificial reservoirs like the recently build reservoirs of the Belo Monte hydropower plant in the Xingu River and future reservoirs planned for the Tapajós River (Winemiller et al., 2016). Clearwater Amazon rivers are the main target in the energy expansion plans of the Brazilian government (EPE/MME, 2007), which regards hydropower as inexpensive and clean energy, however, without consideration of impacts of river impoundment on Amazon ecosystems (Fearnside, 2014; Winemiller et al., 2016) and emission of greenhouse gases (Barros et al., 2011; de Faria et al., 2015). To assess the combined effect of carbon fluxes in Amazon rivers, it is imperative to fully understand carbon burial and emission rates in all main Amazon sedimentary environments. In this paper, we focus on carbon dynamics in the rias of the Xingu and Tapajós rivers. Geochemical, magnetic susceptibility, pollen, and diatom analyses combined with luminescence and radiocarbon dating are used to constrain the sources and fate of carbon in sediments of the Xingu and Tapajós rivers on millennial timescales. We integrated our data and results from previous literature to evaluate the origin and content of organic matter and to understand major controls affecting carbon burial in the Xingu and Tapajós rias.

\section{MATERIALS AND METHODS}

\section{Sediment Sampling}

Sediment cores and samples of riverbed and suspended sediments collected from Xingu, Tapajós and Amazon rivers are presented in Figure 1 and in Supplementary Material (Table S1). Suspended sediment samples were taken both during the dry and wet seasons from Xingu, Tapajós, and Amazon rivers in order to fully encompass variations in sediment composition related to hydrological changes. Suspended and riverbed sediment samples from the Amazon mainstem were 

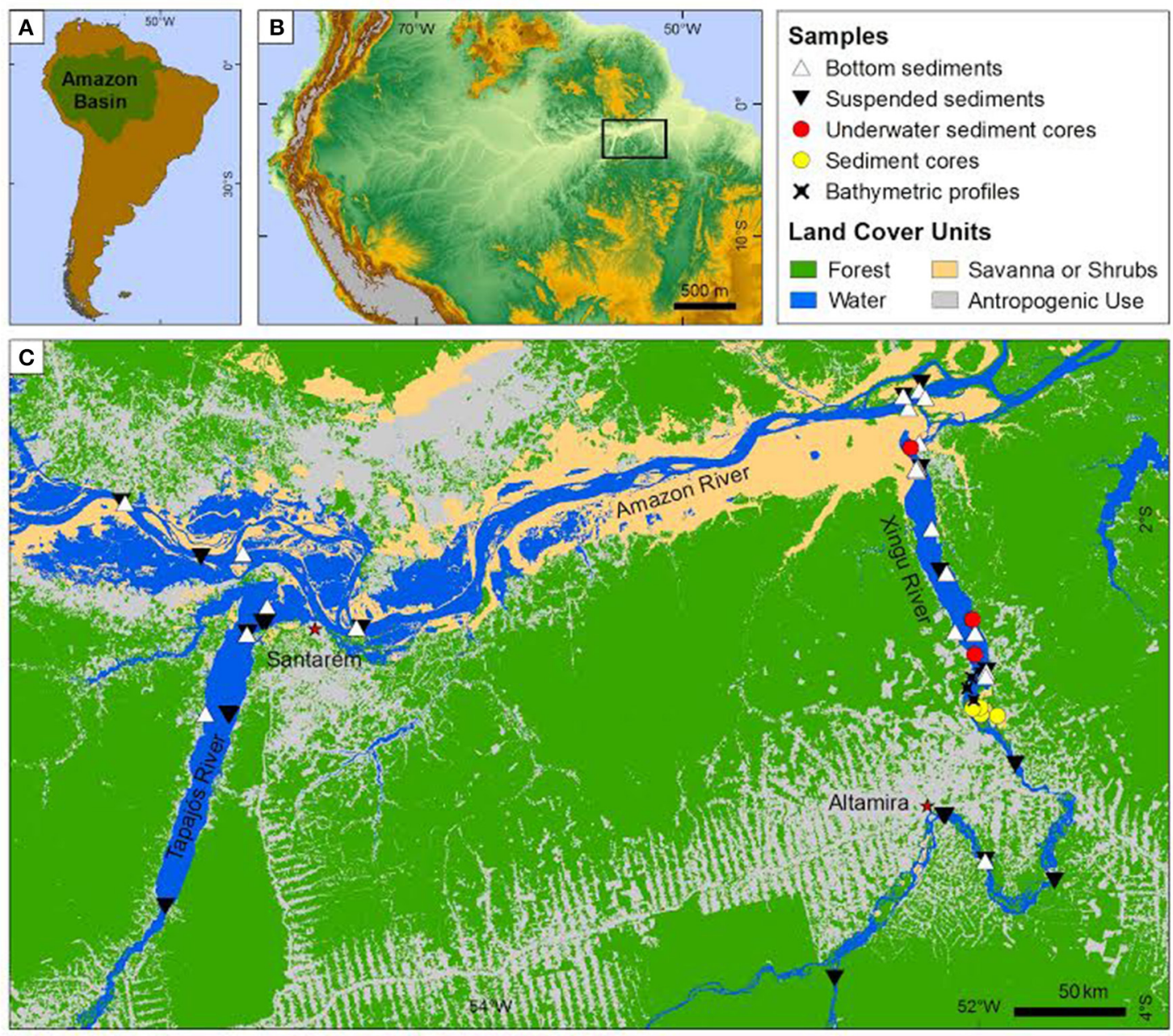

FIGURE 1 | Study area, location of sediment samples (suspended, riverbed and cores) and bathymetric profiles. In this work, underwater sediment cores were named "XC" and sediment cores from islands were named "EMB." Land-use map from Almeida et al. (2016).

collected upstream and downstream the Tapajós and Xingu rivers mouths (Figure 1) in order to evaluate the effect of input of sediments from the Xingu and Tapajós rivers on the Amazon River. Suspended sediment samples were collected through water pumped at approximately $60 \%$ of the water depth in the channel thalweg. For each sample, four liters of water were filtrated using cellulose acetate membranes (pore size of $0.45 \mu \mathrm{m}$ ). Riverbed sediments were collected using a Van Veen grab sampler. A total of 23 suspended sediment samples and 28 riverbed sediment samples were used in this study.

Sediment cores of the Xingu Ria were collected from deeper portions of the lake-like channel covered by muddy sediments (named "XC") and from islands in the upstream section of the Xingu Ria (named "EMB"). The locations were selected based on water depth profiles and riverbed sediment sampling (further details in Sawakuchi et al., 2015). Underwater sediment cores from the Xingu Ria channel were retrieved by divers using PVC tubes of up to $6 \mathrm{~m}$ in length and percussion method (Sawakuchi et al., 2015). Three underwater sediment cores, characterized by dark gray to brown muds with thicknesses of $300 \mathrm{~cm}$ (XC02), $370 \mathrm{~cm}$ (XC03), and $470 \mathrm{~cm}$ (XC05), respectively, were retrieved from the Xingu Ria. Unconsolidated sediments from islands of the Xingu Ria head were collected using a piston-corer attached to a manual auger. Four sediment cores composed of fine to medium sands and muddy organic sediments were obtained from the islands: EMB13-07 (555 cm), EMB13-13 (430 $\mathrm{cm})$, EMB13-17 $(250 \mathrm{~cm})$, and EMB13-21 (345 cm). Samples for luminescence dating were collected using opaque plastic tubes.

Bathymetric profiles were recorded along the upstream part of the Xingu Ria using sonar and GPS equipment. Samples collected with the Van Veen grab sampler were used to characterize riverbed sediments along bathymetric profiles. Water depth profiles and texture of riverbed sediments of the Xingu Ria are shown in Figure 2. 

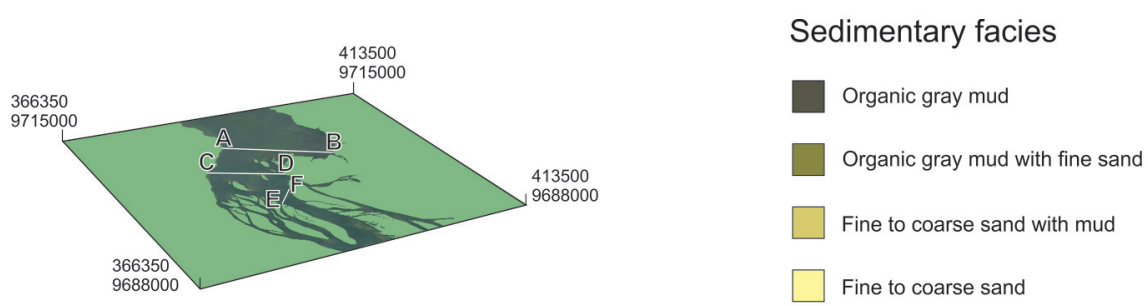

A (NW)

Fine to coarse sand

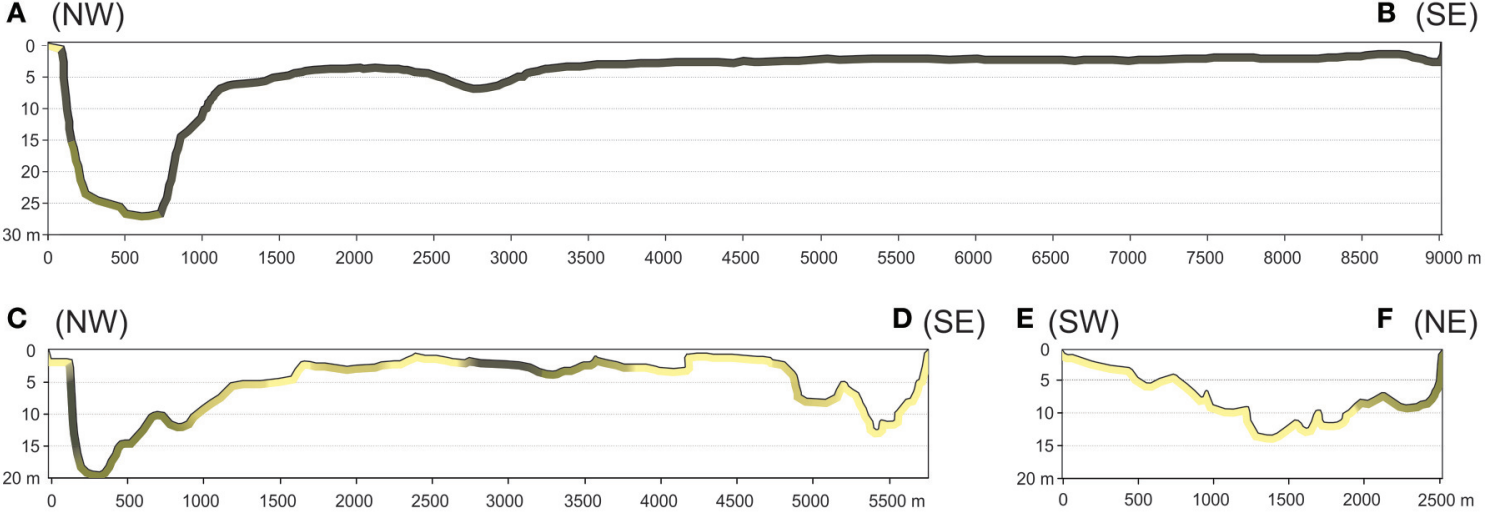

FIGURE 2 | Bathymetry and riverbed sediment texture in the upstream sector of the Xingu Ria.

\section{Organic and Inorganic Geochemistry of Sediments}

Total organic carbon (TOC) content and its stable carbon isotope ratios $\left(\delta^{13} \mathrm{C}_{\text {org }}\right)$ were measured in 28 riverbed sediments samples at MARUM, University of Bremen. Sediments from the core $\mathrm{XC} 05$ were sampled at $2 \mathrm{~cm}$ intervals for total carbon coulometric and $\mathrm{x}$-ray fluorescence (XRF) analysis at the University of Kentucky.

Major elements ( $\mathrm{P}, \mathrm{Ca}, \mathrm{Fe}, \mathrm{Mn}, \mathrm{Al}, \mathrm{Ti}, \mathrm{K}$ ) concentrations were determined with an Agilent 720 inductively coupled plasmaoptical emission spectrometer (ICP-OES) for 23 samples of suspended sediments and with a Bruker Tracer IV SD energy dispersive $\mathrm{x}$-ray fluorescence (XRF) spectrometer for 13 riverbed sediments samples and 234 samples of the sediment core XC05. ICP-OES analysis of suspended sediments and XRF analysis of riverbed sediments were performed at MARUM, University of Bremen. For ICP-OES analysis, digestion of suspended material was performed with a MLS 1200 MEGA microwave system. For this purpose, $7 \mathrm{ml} \mathrm{HNO}_{3}$ (65\%), $0.5 \mathrm{ml} \mathrm{HF}$ (40\%), 0.5 $\mathrm{ml} \mathrm{HCl}(30 \%)$, and $0.5 \mathrm{ml} \mathrm{MilliQ}$ were added to about $50 \mathrm{mg}$ sample material (filter plus suspended material) previously placed into Teflon liners. All acids were of supra-pure quality. For XRF analysis, sediments were prepared by freeze drying, grinding by hand with an agate mortar and pestle, and sieving to $\sim 125 \mu \mathrm{m}$ prior to packing into inert sample boats sealed with an ultra-thin mylar window. Individual XRF scans for each sample were made through the mylar window over $90 \mathrm{~s}$, in order to maximize signal-to-noise. Major elements (atomic numbers 11 through 30) were collected under a $\sim 9$ torr vacuum, by setting the XRF filter to $15 \mathrm{keV}$ and $35 \mu \mathrm{A}$. Trace elements (atomic numbers 20 through 51), were collected at 40
$\mathrm{keV}$ and $15 \mu \mathrm{A}$ without a vacuum. Calibration of unknowns utilized Bruker proprietary software (S1CALPROCESS with TR2.cfz and MA1.cfz) and a reference catalog of mudrock chemistry described in Rowe et al. (2012). Internal consistency of the XRF was verified by routine scanning of the SARM41 shale standard (Ring, 1989). The chief focus of our analysis was the major rock-forming ( $\mathrm{Al}, \mathrm{Ca}, \mathrm{K}, \mathrm{Ti}, \mathrm{P}$ ) and redoxsensitive $(\mathrm{Mn}, \mathrm{Fe})$ elements. Inorganic chemistry data provide insights on mineralogy as well as depositional environments and hydrodynamic processes, especially when paired with organic carbon data (Sageman et al., 2003; Algeo and Rowe, 2012; Scott and Lyons, 2012).

Total organic carbon (TOC) was determined using a LECO CS 200 CS-Analyzing System and an UIC Coulometrics Inc. Carbonate Coulometer (Engleman et al., 1985). The LECO method determines total carbon content through combustion of a powdered sample (Jarvie, 1991). Values of TOC were obtained by subtracting total inorganic carbon determined by the coulometer from total carbon. This method is routinely employed in paleoenvironmental analysis due to its accuracy and small sample size requirements (Jackson and Roof, 1992; Schulte et al., 2000; e.g., Böning et al., 2005). The precision of the analysis, based on analysis of internal standards and replicates, was typically better than $\pm 0.15 \%$. The $\delta^{13} \mathrm{C}_{\text {org }}$ signature of decarbonated samples was analyzed on a Finnigan MAT Delta plus coupled to a CE elemental analyzer. $\delta^{13} \mathrm{C}_{\text {org }}$ is reported using the delta notation relative to the Vienna Pee Dee Belemnite (VPDB). The uncertainty was less than $\pm 0.1 \%$.

Results were analyzed using R software (R Core Team, 2015). Major changes in hydrology and paleoenvironmental conditions were determined using constrained hierarchical cluster analysis 
of geochemistry and magnetic susceptibility data by the method of incremental sum of squares (CONISS, Grimm, 1987).

\section{Magnetic Susceptibility}

Magnetic susceptibility measurements were performed at the Paleomagnetic Laboratory (USPMag) of the Institute of Astronomy, Geophysics and Atmospheric Sciences of the University of São Paulo (IAG/USP). Magnetic susceptibility is used here as a complimentary method to identify significant variations in paleoenvironmental conditions or sediment composition in core XC05. A total of 194 paleomagnetic specimens were collected from the sediment core using cubic plastic boxes $\left(8 \mathrm{~cm}^{3}\right)$ placed side-by-side throughout the core. Low-field magnetic susceptibility of individual specimen was measured using a Kappabridge MFK1-FA system (AGICO Ltd). Two different frequencies $(976$ and $15616 \mathrm{~Hz}$ ) were used in a 200 $\mathrm{Am}^{-1}$ field at room temperature (Dearing et al., 1996). All data were mass normalized due to the irregular sample mass inside cubic boxes.

\section{Pollen and Diatom Analyses}

Riverbed samples were subsampled for pollen analyses (Table S1). Samples were processed for extraction of pollen grains using the protocol established by Colinvaux et al. (1999). The analyses were performed in the Institute of Geosciences of the University of São Paulo (IGc/USP) under a microscope with magnification of 600x. A minimum of 300 terrestrial pollen grains were counted per sample. Aquatic taxa and spores are not included in the sum of pollen assemblage. The pollen grains and spores were identified using the pollen reference collection of the University of São Paulo and other published reference materials (Erdtman, 1952; Roubik and Moreno, 1991; Colinvaux et al., 1999). The raw pollen count data were entered into the Tilia software (Grimm, 2011), in order to calculate the taxa percentages and concentrations.

Riverbed and sediment core XC05 were subsampled for diatom analyses. Diatom analysis followed standard procedures discussed by Battarbee et al. (2001). Slides were mounted with Naphrax ${ }^{\circledR}$ as medium. Optical observations and counts were conducted at a magnification of 1000x with a Zeiss Axioskop 2 plus microscope. At least 400 valves were counted per slide. Taxonomy and nomenclature followed published literature sources (e.g., Round et al., 1990; Krammer, 2000; Rumrich et al., 2000; Metzeltin and Lange-Bertalot, 2007) and the on-line catalog of valid names (California Academy of Sciences, 2011).

\section{$\mathrm{CH}_{4}$ and $\mathrm{CO}_{2}$ in Sediment Pore Waters}

Sediment core XC05 was sub-sampled in field on the same day of collection for the assessment of dissolved methane and carbon dioxide concentrations in pore waters. Aliquots of 5 $\mathrm{ml}$ of wet sediment were collected with an open-ended $5 \mathrm{ml}$ polypropylene syringe after carefully drilling holes at $10 \mathrm{~cm}$ intervals. Immediately after collection, the aliquots were injected into a $120 \mathrm{ml}$ vial containing $10 \mathrm{ml}$ of $\mathrm{NaOH}$ (5\%), capped with butyl rubber stoppers and sealed with aluminum crimps. Control standards of ambient air were collected during sampling for corrections. In the Center for Nuclear Energy in Agriculture of the University of São Paulo (CENA/USP), samples were shaken for headspace equilibration and $60 \mathrm{ml}$ of gas sample was retrieved from vials headspace using a $60 \mathrm{ml}$ syringe and analyzed by Cavity Ring Down Spectroscopy using a Picarro G2201-i device. Samples were slowly injected following the pump flow, taking care not to change the internal pressure, which can be monitored by the analyzer. The $60 \mathrm{ml}$ analyzes took approximately 3 min to pass through the analyzer giving a steady measurement for roughly $40 \mathrm{~s}$ that was checked with three standard gas mixtures for concentration and carbon isotope composition of $\mathrm{CH}_{4}$. Reproducibility between replicates presented a variation of the standard deviation $>0.5 \%$ for concentration and $>0.9 \%$ for $\delta^{13} \mathrm{C}_{\mathrm{CH} 4}$. Readings of concentration (ppm) and $\delta^{13} \mathrm{C}_{\mathrm{CH}} 4$ (\%) by the analyzer were slightly different than the standard reference values. Thus, sample results were corrected according to a standard calibration curve.

\section{Optically Stimulated Luminescence and Radiocarbon Datings}

Optically stimulated luminescence (OSL) dating was carried out in fine silt or sand quartz aliquots from cores $\mathrm{XC02}, \mathrm{XC03}$, and $\mathrm{XC05}$ in the Luminescence and Gamma Spectrometry Laboratory of the IGc/USP. Quartz aliquots for luminescence measurements were prepared under subdued red light. Wet sieving and settling procedures were used to isolate the 411 or $180-250 \mu \mathrm{m}$ grain sizes. The target grain size fractions were submitted to oxygen peroxide $\left(\mathrm{H}_{2} \mathrm{O}_{2}\right)$ and hydrochloric ( $\mathrm{HCl} 10 \%)$ treatments to remove organic matter and carbonates, respectively. Heavy liquid separation of quartz sand grains was performed using lithium metatungstate solution at densities of 2.75 and $2.62 \mathrm{~g} \mathrm{~cm}^{-3}$ to remove heavy minerals and feldspar grains, respectively. Concentrates of quartz sand grains were etched with hydrofluoric acid (HF 38\%) for $40 \mathrm{~min}$ in order to remove the outer rind of quartz grains damaged by alpha particles and remnant feldspar grains. Luminescence measurements were performed in two automated Risø OSL/TL reader model DA20 equipped with blue $(470 \mathrm{~nm})$ and infrared $(870 \mathrm{~nm})$ LEDs for light stimulation, Hoya U-340 filter for light detection in the ultraviolet band and built-in beta radiation sources $\left({ }^{90} \mathrm{Sr} /{ }^{90} \mathrm{Y}\right)$ delivering dose rates of 0.088 and $0.135 \mathrm{~Gy} \mathrm{~s}^{-1}$ (for aluminum discs). Equivalent doses were determined through the singlealiquot regenerative dose protocol (Murray and Wintle, 2000). For fine silt, a mean a-value of 0.04 was considered for calculation of alpha dose rate in quartz. Tests with infrared stimulation indicated absence of feldspar in the fine silt concentrates. A dose recovery test was performed to set up the luminescence measurements protocol to the studied samples batch. Samples equivalent doses were calculated through the Central Age Model (Galbraith et al., 1999). The concentrations of $\mathrm{K},{ }^{238} \mathrm{U}$ and ${ }^{232} \mathrm{Th}$ for dose rate calculations were determined using high resolution gamma spectrometry with a high purity germanium detector (relative efficiency of 55\% and energy resolution of $2.1 \mathrm{KeV}$ ) encased in an ultralow background shield. Samples were packed in sealed plastic containers and stored for at least 28 days for radon equilibration before gamma spectrometry. Radiation dose rates were calculated using conversion factors outlined by Guérin et al. (2011). Radiation dose rates were corrected for water 
saturation (water weight/dry sample weight). Cosmic dose rates were calculated through samples latitude, longitude, elevation and burial depth, according to Prescott and Hutton (1994).

Accelerator mass spectrometry (AMS) radiocarbon $\left({ }^{14} \mathrm{C}\right)$ dating was performed on leaves and charcoal fragments retrieved from the sediment cores. Samples were treated in the Radiocarbon Laboratory of the Illinois State Geological Survey and submitted to the Keck Carbon Cycle AMS Laboratory of the University of California-Irvine for AMS ${ }^{14} \mathrm{C}$ analysis. The ${ }^{14} \mathrm{C}$ dates were calibrated using the program Calib 7.0 and the calibration curve IntCal 13 (Stuiver and Reimer, 1993; Reimer et al., 2013).

\section{RESULTS}

\section{Geochemistry of Suspended and Riverbed Sediments}

Geochemical results are summarized in Tables 1, 2 (discretized dataset in Table S1). Strong variations in suspended sediment composition were identified between wet and dry seasons in the Xingu, Tapajós, and Amazon rivers (Table 1, Figure 3). Seasonal changes in suspended sediments of the Xingu and Tapajós rivers include the increase in the relative amount of $\mathrm{P}$ in sediments of the dry season, which is directly related to primary productivity (Engstrom and Wright, 1984; Dean and Gorham, 1998). The $\mathrm{P} / \mathrm{Ti}$ ratio is an effective proxy to evaluate the sedimentation of phosphorous regardless of terrigenous input and it avoids dilution effects caused by changes in sedimentation rate (Latimer and Filippelli, 2002; Filippelli et al., 2003). Average P/Ti ratios in the Xingu River vary from 0.66 in the wet season to 4.20 in the dry season. Seasonal changes in $\mathrm{P}$ concentration have lower amplitudes in the Tapajós River, with the $\mathrm{P} / \mathrm{Ti}$ ratio shifting from 0.75 to 0.94 from the wet to the dry seasons, respectively. The $\mathrm{Fe} / \mathrm{K}$ ratio is a useful indicator of mineralogical stability, since the most stable rock-forming minerals have lower $\mathrm{Fe} / \mathrm{K}$ ratios (K-feldspar, muscovite, and quartz) and unstable minerals tend to be richer in iron content (Herron, 1988; Armstrong-Altrin and Machain-Castillo, 2016). Fe/K ratios increase during the wet season both in the Xingu and Tapajós rivers, with relatively little variation in the Amazon River (Table 3). In the Xingu River, Ca concentrations increase from 0.09 to $0.35 \mathrm{mg} \mathrm{l}^{-1}$ and $\mathrm{P}$ concentration from 0.03 to $0.71 \mathrm{mg} \mathrm{l}^{-1}$ between the wet and
TABLE 2 | Summary of major elements concentrations, TOC and $\delta 13 C_{\text {org }}$ of bulk organic matter in bottom sediments of the Xingu, Tapajós, and Amazon rivers.

\begin{tabular}{lccc}
\hline River & Xingu & Tapajós & Amazon \\
\hline$n$ & 5 & 2 & 7 \\
$\mathrm{Mg}(\mathrm{mg} / \mathrm{kg})$ & $1547 \pm 737$ & 5803 & $6009 \pm 180$ \\
$\mathrm{Al}(\mathrm{mg} / \mathrm{kg})$ & $75685 \pm 7649$ & $54944 \pm 20699$ & $70821 \pm 2270$ \\
$\mathrm{~K}(\mathrm{mg} / \mathrm{kg})$ & $7342 \pm 1577$ & $8772 \pm 7754$ & $15204 \pm 418$ \\
$\mathrm{Ca}(\mathrm{mg} / \mathrm{kg})$ & $3195 \pm 608$ & $3592 \pm 1904$ & $5987 \pm 222$ \\
$\mathrm{Ti}(\mathrm{mg} / \mathrm{kg})$ & $3119 \pm 425$ & $3111 \pm 1642$ & $4366 \pm 67$ \\
$\mathrm{Mn}(\mathrm{mg} / \mathrm{kg})$ & $330 \pm 99$ & $226 \pm 183$ & $438 \pm 51$ \\
$\mathrm{Fe}(\mathrm{mg} / \mathrm{kg})$ & $26999 \pm 7462$ & $16367 \pm 13823$ & $25948 \pm 1702$ \\
$\mathrm{Si}(\mathrm{mg} / \mathrm{kg})$ & $196160 \pm 13454$ & $228105 \pm 1280$ & $221458 \pm 4768$ \\
$\mathrm{TOC}(\%)$ & $2.25 \pm 0.582$ & 0.2 & $0.59 \pm 0.068$ \\
$\delta 13 \mathrm{C}_{\mathrm{org}}(\%)$ & $-28.645 \pm 0.288$ & - & $-28.02 \pm 0.201$
\end{tabular}

Data of individual samples are presented in Table S1 of the Supplementary Material.

dry season. Fe concentrations shift from 1.11 to $2.56 \mathrm{mg} \mathrm{l}^{-1}$ from the wet to the dry season. The inverse pattern is observed in the Amazon River, with $\mathrm{Ca}, \mathrm{P}$, and Fe concentrations decreasing in the dry season (Table 1, Figure 3). In the Tapajós River, these shifts between wet and dry seasons have lower amplitude, with $\mathrm{Ca}$ concentration varying from 0.07 to $0.13 \mathrm{mg} \mathrm{l}^{-1}, \mathrm{P}$ varying from 0.03 to $0.05 \mathrm{mg} \mathrm{l}^{-1}$ and Fe varying from 0.99 to $0.76 \mathrm{mg} \mathrm{l}^{-1}$.

\section{Pollen and Diatoms in Riverbed and Core Sediments}

In total, 45 pollen taxa were identified in riverbed sediments of the Xingu Ria (Figures S1-S4). The vegetation represented by pollen retrieved from riverbed sediments has great diversity and high percentages of forest elements. Arboreal taxa encountered in the samples include Acalypha, Alchornea, Annacardiaceae, Apocynaceae, Arecaceae, Attalea, Bignoniaceae, Cecropia, Combretum, Dalbergia, Didymopanax, Euterpe, Fabacea, Genipa, Machaerium, Mauritia, Mauritiella, Matayba, Melastomataceae, Mimosa, Myrtaceae, Palmae, Psidium, Psychotria, Sapium, Spondias, Sterculiaceae, Stigmaphyllon, Talisia, and Zygia. Terrestrial herbaceous elements are represented by Alternanthera, Asteraceae, Bambusa, Begonia, Caesaria, Lamiaceae, Phyllanthus, Pilea, Poaceae, Polygonaceae

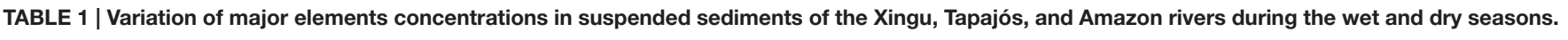

\begin{tabular}{|c|c|c|c|c|c|c|c|c|c|c|}
\hline River & Season & $n$ & Mg (mg/l) & $\mathrm{Al}(\mathrm{mg} / \mathrm{l})$ & K (mg/l) & $\mathrm{Ca}(\mathrm{mg} / \mathrm{l})$ & Ti (mg/l) & Mn (mg/l) & $\mathrm{Fe}(\mathrm{mg} / \mathrm{l})$ & $P(m g / l)$ \\
\hline \multirow[t]{2}{*}{ Xingu } & dry & 6 & $0.30 \pm 0.102$ & $6.31 \pm 1.205$ & $0.80 \pm 0.272$ & $0.35 \pm 0.068$ & $0.22 \pm 0.057$ & $0.19 \pm 0.022$ & $2.56 \pm 0.572$ & $0.71 \pm 0.051$ \\
\hline & wet & 5 & $0.07 \pm 0.009$ & $1.72 \pm 0.283$ & $0.06 \pm 0.014$ & $0.09 \pm 0.015$ & $0.05 \pm 0.011$ & $0.05 \pm 0.006$ & $1.11 \pm 0.110$ & $0.03 \pm 0.003$ \\
\hline \multirow[t]{2}{*}{ Tapajós } & dry & 4 & $0.09 \pm 0.023$ & $2.37 \pm 0.650$ & $0.08 \pm 0.023$ & $0.13 \pm 0.027$ & $0.06 \pm 0.015$ & $0.12 \pm 0.23$ & $0.76 \pm 0.150$ & $0.05 \pm 0.004$ \\
\hline & wet & 3 & $0.05 \pm 0.006$ & $1.68 \pm 0.350$ & $0.03 \pm 0.019$ & $0.07 \pm 0.027$ & $0.04 \pm 0.007$ & $0.03 \pm 0.006$ & $0.99 \pm 0.251$ & $0.03 \pm 0.008$ \\
\hline \multirow[t]{2}{*}{ Amazon } & dry & 2 & $0.46 \pm 0.055$ & $5.47 \pm 0.737$ & $0.81 \pm 0.140$ & $0.38 \pm 0.035$ & $0.21 \pm 0.032$ & $0.04 \pm 0.005$ & $2.50 \pm 0.266$ & $0.05 \pm 0.002$ \\
\hline & wet & 3 & $2.24 \pm 0.269$ & $23.43 \pm 2.122$ & $5.01 \pm 0.613$ & $1.63 \pm 0.195$ & $1.19 \pm 0.164$ & $0.18 \pm 0.027$ & $14.40 \pm 1.051$ & $0.27 \pm 0.017$ \\
\hline
\end{tabular}

Data of individual samples are presented in Table S1 of the Supplementary Material. 

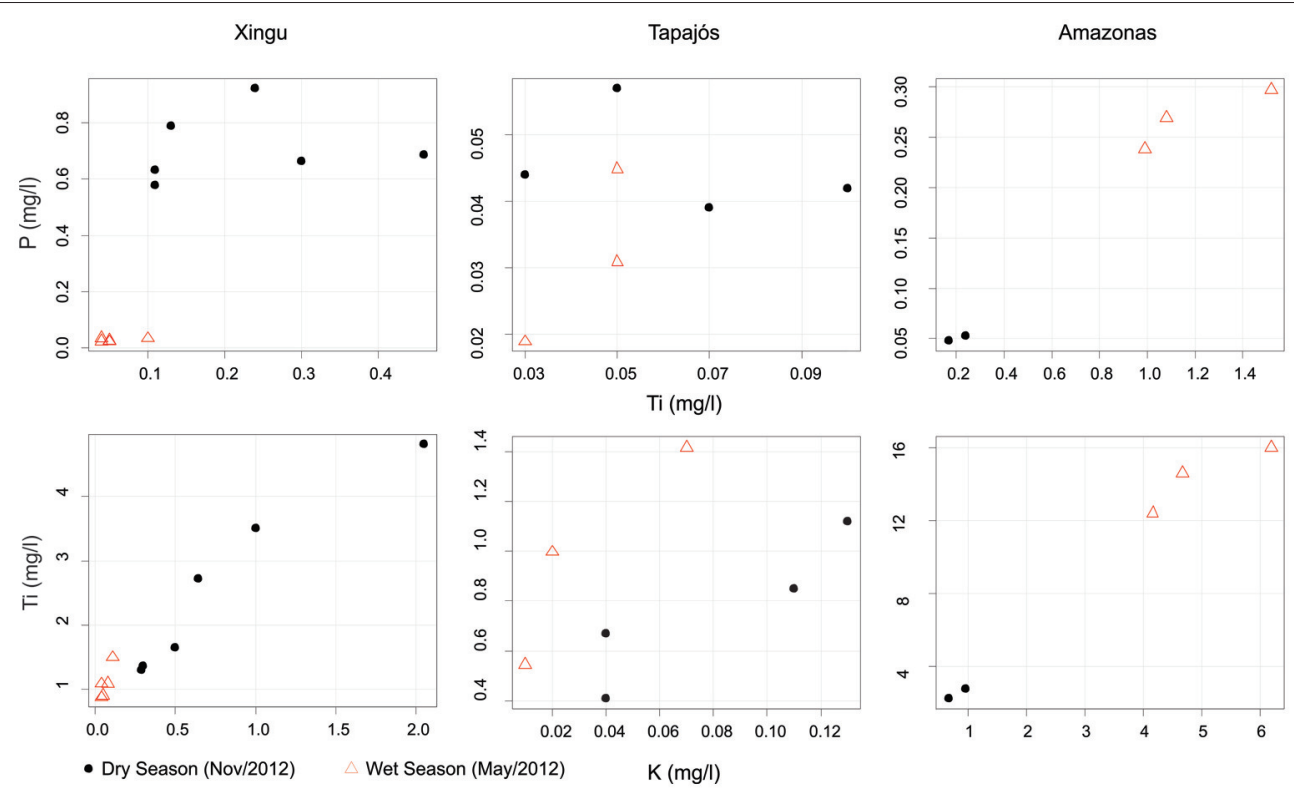

FIGURE 3 | Scatterplots comparing P, Ti and K concentrations in suspended sediments collected in the Xingu, Tapajós and Amazon rivers during the wet and dry seasons.

TABLE 3 | Variation of elemental ratios in suspended sediments of the Xingu, Tapajós, and Amazon rivers during the wet and dry seasons.

\begin{tabular}{|c|c|c|c|c|c|c|c|c|c|c|c|c|}
\hline River & Season & $n$ & $\mathrm{Fe} / \mathrm{K}$ & $\mathbf{P} / \mathbf{K}$ & $\mathrm{Ti} / \mathrm{Ca}$ & $\mathrm{Mn} / \mathrm{K}$ & $\mathrm{P} / \mathrm{Mg}$ & $\mathrm{Fe} / \mathrm{Ca}$ & $\mathrm{P} / \mathrm{Ti}$ & $\mathrm{Fe} / \mathrm{Mn}$ & Ti/Al & $\mathrm{Al} / \mathrm{Ca}$ \\
\hline \multirow[t]{2}{*}{ Xingu } & dry & 6 & 3.74 & 1.35 & 0.61 & 0.35 & 3.45 & 7.24 & 4.20 & 13.36 & 0.034 & 18.37 \\
\hline & wet & 5 & 19.15 & 0.58 & 0.59 & 0.93 & 0.45 & 12.54 & 0.66 & 24.67 & 0.031 & 19.01 \\
\hline \multirow[t]{2}{*}{ Tapajós } & dry & 4 & 10.84 & 0.80 & 0.50 & 2.29 & 0.63 & 6.26 & 0.94 & 7.55 & 0.026 & 19.32 \\
\hline & wet & 3 & 41.76 & 1.36 & 0.76 & 1.36 & 0.62 & 16.86 & 0.75 & 32.11 & 0.025 & 29.75 \\
\hline \multirow[t]{2}{*}{ Amazonas } & dry & 2 & 3.12 & 0.06 & 0.54 & 0.04 & 0.11 & 6.65 & 0.25 & 71.67 & 0.038 & 14.52 \\
\hline & wet & 3 & 2.91 & 0.05 & 0.73 & 0.03 & 0.12 & 8.93 & 0.23 & 83.52 & 0.051 & 14.47 \\
\hline
\end{tabular}

and Symmeria. Sagitaria, Cyperaceae, Alismataceae represent taxa of aquatic herbs. Spores identified in the analysis include Polypodiaceae, trilete and Monolete. The palynologic data indicate that riverbed sediments of the Xingu Ria record the input of sediments from areas where the predominant vegetation type is forest (Figure S5).

Regarding the diatoms, a total of 65 infrageneric taxa were identified in riverbed sediments of the Xingu Ria. Eunotia and Gomphonema were the most represented genera regarding species number $(24.6 \%$ of total species), followed by genus Aulacoseira (9.2\%) (Figure S6). Eunotia species are mostly acidophilic, oligotrophic, and typified by a dominant periphytic habitat (Round et al., 1990; van Dam et al., 1994; Moro and Fürstenberger, 1997; Hamilton and Siver, 2010). Due to the secretion of mucilage by the apical pore fields, Gomphonema is a common genus in periphytic algal communities, being well represented in richness and density (Tremarin et al., 2009). Aulacoseira is a common planktonic genus inhabiting lacustrine and running freshwaters, developing in various trophic conditions (Denys et al., 2003; Zalat and Vildary, 2007).
Ecological information at species level is required to use this genus as indicator of water quality (Bicudo et al., 2016).

Diatoms presented well-preserved frustules throughout the core. Assemblages from the core XC05 base showed little variation among genera, and besides the planktonic genus Aulacoseira, comprised benthic and periphytic genera that require surfaces for developing (e.g., Eunotia, Pinnularia and Surirella), suggesting a water column under acidic and oligotrophic conditions with high light penetration. Genera Surirella, Diploneis, Aulacoseira, Placoneis, Gomphonema, Encyonema, and Eunotia were observed throughout the core, suggesting a relatively uniform slack water environment.

\section{Chronology, Magnetic and Geochemistry Data of Sediment Cores}

Sediments of the three studied underwater cores (XC02, XC03, and $\mathrm{XC05}$ ) are composed of dark gray to brown organic-rich muddy sediments. As highlighted in Figure 2, these sediments are similar to the modern surface sediments that accumulate in 


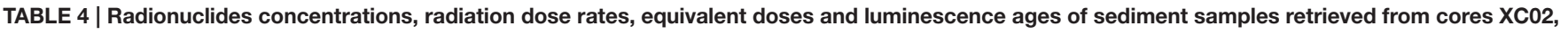
$\mathrm{XC03}$, and XC05.

\begin{tabular}{|c|c|c|c|c|c|c|c|c|}
\hline Sample & Depth (cm) & U (ppm) & Th (ppm) & K (\%) & $\begin{array}{c}\text { Cosmic dose rate } \\
\qquad(\mathrm{Gy} / \mathrm{ka})\end{array}$ & $\begin{array}{l}\text { Total dose rate } \\
\qquad(\mathrm{Gy} / \mathrm{ka})\end{array}$ & $\begin{array}{l}\text { Equivalent } \\
\text { dose (Gy) }\end{array}$ & $\begin{array}{c}\text { Age } \\
\text { (years) }\end{array}$ \\
\hline XC02-10 & 10 & $5.35 \pm 2.66 \mathrm{E}-1$ & $1.50 \pm 8.87 \mathrm{E}-1$ & $0.67 \pm 0.06$ & $0.19 \pm 0.01$ & $1.72 \pm 0.29$ & $4.3 \pm 0.3$ & $2503 \pm 462$ \\
\hline XC02-293 & 293 & $4.54 \pm 2.12 \mathrm{E}-1$ & $15.58 \pm 8.30 \mathrm{E}-1$ & $0.67 \pm 0.05$ & $0.13 \pm 0.01$ & $1.7 \pm 0.28$ & $5.6 \pm 0.1$ & $3295 \pm 542$ \\
\hline XC03-10 & 10 & $3.70 \pm 1.87 \mathrm{E}-1$ & $7.66 \pm 5.10 \mathrm{E}-1$ & $1.13 \pm 0.06$ & $0.19 \pm 0.02$ & $2.55 \pm 0.41$ & $0.3 \pm 0.2$ & $118 \pm 81$ \\
\hline XC03-363 & 363 & $3.19 \pm 1.67 \mathrm{E}-1$ & $6.48 \pm 4.55 \mathrm{E}-1$ & $1.14 \pm 0.06$ & $0.12 \pm 0.01$ & $2.48 \pm 0.41$ & $3.1 \pm 0.1$ & $1251 \pm 211$ \\
\hline XC05-45 & 45 & $4.53 \pm 1.69 \mathrm{E}-1$ & $19.95 \pm 7.64 \mathrm{E}-1$ & $0.7 \pm 0.04$ & $0.08 \pm 0.01$ & $2.05 \pm 0.08$ & $6.2 \pm 0.3$ & $3025 \pm 185$ \\
\hline XC05-140 & 140 & $4.73 \pm 1.77 \mathrm{E}-1$ & $20.94 \pm 8.01 \mathrm{E}-1$ & $0.741 \pm 0.04$ & $0.07 \pm 0.01$ & $2.21 \pm 0.09$ & $7.1 \pm 0.1$ & $3219 \pm 133$ \\
\hline XC05-239 & 239 & $4.36 \pm 1.69 \mathrm{E}-1$ & $21.86 \pm 8.35 \mathrm{E}-1$ & $0.74 \pm 0.045$ & $0.07 \pm 0.01$ & $2.17 \pm 0.08$ & $7.3 \pm 0.1$ & $3360 \pm 138$ \\
\hline XC05-340 & 340 & $4.34 \pm 1.66 \mathrm{E}-1$ & $20.72 \pm 7.98 \mathrm{E}-1$ & $0.71 \pm 0.04$ & $0.06 \pm 0.01$ & $1.99 \pm 0.07$ & $7.4 \pm 0.1$ & $3718 \pm 147$ \\
\hline XC05-440 & 440 & $4.16 \pm 1.62 \mathrm{E}-1$ & $2.21 \pm 8.3 \mathrm{E}-1$ & $0.791 \pm 0.04$ & $0.06 \pm 0.01$ & $2.06 \pm 0.08$ & $8.4 \pm 0.1$ & $4086 \pm 159$ \\
\hline
\end{tabular}
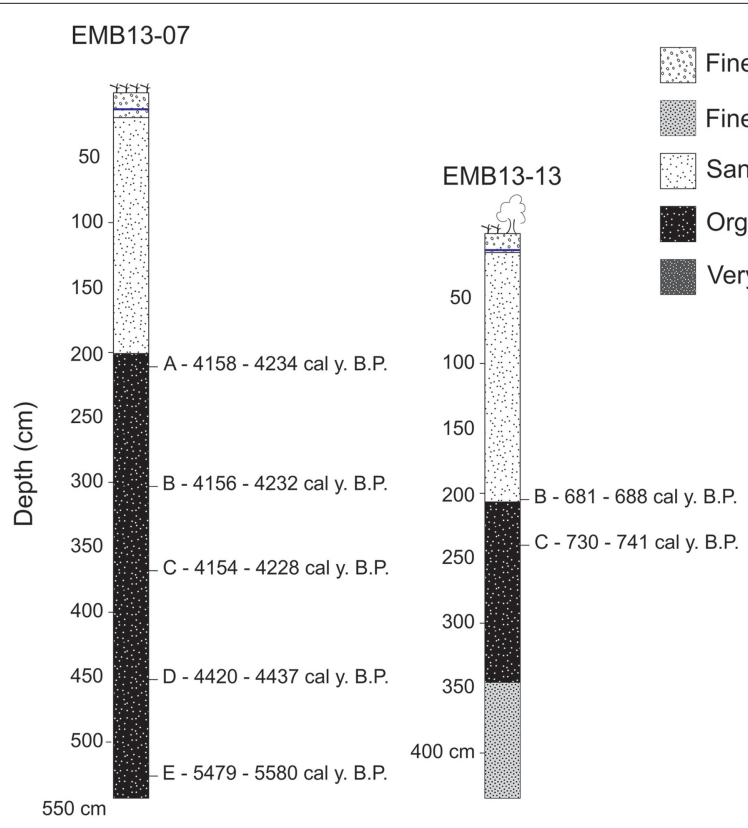

Fine-grained to sandy soil with leaves and roots

Fine to medium sand with mud

Sandy silt

Organic-rich silt with clay

Very fine to fine sand

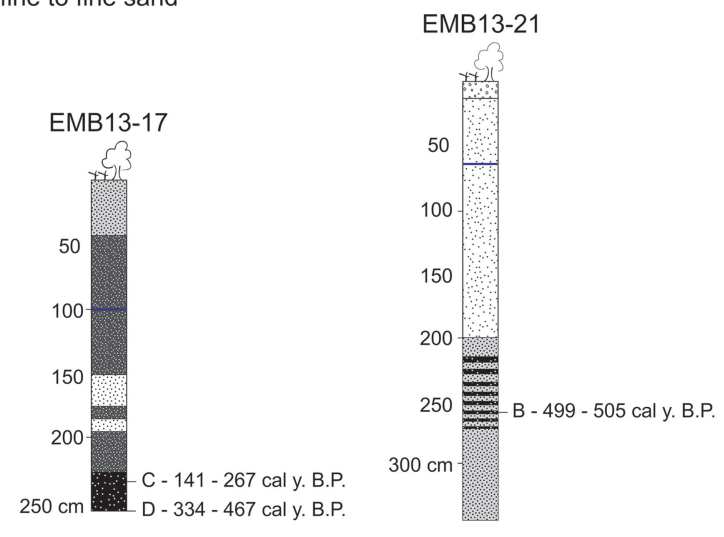

FIGURE 4 | Radiocarbon ages in sediment depth profiles of stabilized bar of the Xingu Ria head. Ria sediments are represented by organic-rich muds buried by organic-poor floodplain sediments.

most of the rias. Samples from the top and bottom of sediment cores XC02 $(10-293 \mathrm{~cm}), \mathrm{XC03}(10-363 \mathrm{~cm})$ and XC05 (45$440 \mathrm{~cm}$ ) were collected for OSL dating. The luminescence ages of cores XC02, XC03, and XC05 ranged from $118 \pm 81$ to $4,086 \pm 159$ years (Table 4), suggesting that the Xingu Ria is a slack water environment acting as trap of fine-grained sediments at least since the middle Holocene. XC02 sediments showed ages from 2,503 \pm 462 to $3,295 \pm 542$ years. XC03 and XC05 sediments cover periods from $118 \pm 81$ to $1,251 \pm 211$ years, and from $3,025 \pm 185$ to $4,086 \pm 159$ years, respectively. Sediment depth profiles described in the islands of the head of the Xingu Ria (EMB13-07, EMB13-13 and EMB13-17) show dark gray organic-rich sediments interlayered with sands and light gray floodplain sediments (Figure 4). Radiocarbon ages obtained in the dark gray muds, which likely represent buried ria sediments, varied from 141-267 to 5,479-5,580 cal years BP (Table 5, Figure 4).

Luminescence and radiocarbon ages allowed the calculation of sedimentation rates for the organic-rich sediments of the Xingu Ria. In the Xingu Ria, sedimentation rates calculated through luminescence ages of core XC05 varied between $0.27 \mathrm{~cm} \mathrm{yr}^{-1}$ and $0.70 \mathrm{~cm} \mathrm{yr}^{-1}$ (average of $0.37 \mathrm{~cm} \mathrm{yr}^{-1}$ ). The rate of deposition of core XC05 increases from about $0.28 \mathrm{~cm} \mathrm{yr}^{-1}$ during the period of $\sim 4,100$ to $\sim 3,300$ years ago to an average of $0.60 \mathrm{~cm} \mathrm{yr}^{-1}$ during the period of $\sim 3,300$ to $\sim 3,000$ years ago. Cores $\mathrm{XC0} 2$ and XC03 presented average sedimentation rates of $0.36 \mathrm{~cm} \mathrm{yr}^{-1}$ and $0.31 \mathrm{~cm} \mathrm{yr}^{-1}$, respectively. Sedimentation rates for organicrich sediments underneath floodplain sediments of the Xingu Ria head were $0.24 \mathrm{~cm} \mathrm{yr}^{-1}, 0.78 \mathrm{~cm} \mathrm{yr}^{-1}, 0.05 \mathrm{~cm} \mathrm{yr}^{-1}$ in profiles EMB13-07, EMB13-13 and EMB13-17, respectively (Figure 4). 
TABLE 5 | Radiocarbon ages of sediment cores EMB13-07, EMB13-13, EMB13-17, and EMB13-21.

\begin{tabular}{llccc}
\hline Sample & $\begin{array}{l}\text { Analyzed } \\
\text { material }\end{array}$ & $\begin{array}{c}\text { Depth } \\
\mathbf{( c m )}\end{array}$ & $\begin{array}{c}\mathbf{1 4}^{\mathbf{C}} \text { Age } \\
\text { (years BP) }\end{array}$ & $\begin{array}{c}\text { Calibrated }{ }^{\mathbf{1 4}} \mathbf{C} \text { age } \\
\text { (cal years BP) }\end{array}$ \\
\hline EMB13-07 A & leaf & 210 & $3185 \pm 15$ & $4158-4234$ \\
EMB13-07 B & leaf & 303 & $3180 \pm 15$ & $4156-4232$ \\
EMB13-07 C & leaf & 373 & $3805 \pm 20$ & $4154-4228$ \\
EMB13-07 D & leaf & 458 & $3975 \pm 15$ & $4420-4437$ \\
EMB13-07 E & leaf & 532 & $4765 \pm 25$ & $5479-5580$ \\
EMB13-13 B & charcoal & 210 & $765 \pm 15$ & $681-688$ \\
EMB13-13 C & leaf & 248 & $835 \pm 15$ & $730-741$ \\
EMB13-17 C & leaf & 230 & $145 \pm 15$ & $141-267$ \\
EMB13-17 D & charcoal & 240 & $360 \pm 20$ & $334-467$ \\
EMB13-21 B & charcoal & 260 & $425 \pm 15$ & $499-505$ \\
\hline
\end{tabular}

In the Tapajós Ria, sedimentation rates were calculated through radiocarbon ages presented in Irion et al. (2006). Rates of sediment deposition in the Tapajós Ria vary from $0.24 \mathrm{~cm} \mathrm{yr}^{-1}$ to $0.65 \mathrm{~cm} \mathrm{yr}^{-1}$ (average of $0.37 \mathrm{~cm} \mathrm{yr}^{-1}$ ).

Magnetic susceptibility measurements were performed on the XC05 core. Low-field magnetic susceptibility varies from $3.4 \times 10^{-8}$ to $1.9 \times 10^{-7} \mathrm{~m}^{3} \mathrm{~kg}^{-1}$ (Figure 5). Strong magnetic susceptibility variations (peaks) may indicate variations in sedimentation rate or increased magnetic mineral concentrations. The dendogram of geochemical data demonstrates abrupt shifts in the compositional similarity of sediments deposited at 3,690-3,650, 3,345-3,335, and 3,2353,240 years ago. These shifts fit well with peaks in magnetic susceptibility and $\mathrm{P}, \mathrm{Fe}, \mathrm{Mn}$, and TIC concentration as well as with the decrease in TOC and lithophilic elements (Figure 5).

Ti concentration reveals significant positive correlations with $\mathrm{Al}(r=0.81, n=198)$ and $\mathrm{K}(r=0.75, n=198)$. These elements were used as proxies for the relative contribution of terrigenous sediment input from the Xingu River to the downstream Xingu Ria lake (Engstrom and Wright, 1984; Boës et al., 2011). Results show significant inverse correlation among $\mathrm{P}$ concentration and lithophilic elements represented by $\mathrm{Ti}(r=-0.31, n=198), \mathrm{Al}$ $(r=-0.32, n=198)$ and $\mathrm{K}(r=-0.46, n=198)$. P concentration also shows significant positive correlations with $\mathrm{Fe}(r=0.57$, $198)$, TIC ( $r=0.51, n=198)$ and $\operatorname{Mn}(r=0.51, n=198)$.

Total organic carbon (TOC) concentration varies between 1.77 and $3.35 \%$ (average of $2.45 \%$ ) in sediment core XC05. The measured concentrations are similar to values in samples from bottom sediments of the Xingu Ria (Häggi et al., 2016). Values of $\delta^{13} \mathrm{C}_{\text {org }}$ range from -31.04 to $-27.49 \%$, and indicate that organic matter from bottom sediments of the Xingu Ria is mainly derived from arboreal C3 vegetation (Table S1). This is supported by palynological data, with pollen assemblages dominated by forest taxa (Figure S1).

$\mathrm{CH}_{4}$ concentrations in pore waters reach values up to $25 \%$ (volume) in XC05 sediment core (Figure 5). The values of $\delta^{13} \mathrm{C}_{\mathrm{CH} 4}$ in pore waters of XC05 core range from -71 to $-57 \%$ PDB. Higher (more positive) values of $\delta^{13} \mathrm{C}_{\mathrm{CH} 4}$ often agree with peaks in magnetic susceptibility, Fe concentration and $\mathrm{P} / \mathrm{Ti}$
(Figure 5). This suggests that $\mathrm{CH}_{4}$ oxidation in pore waters might increase during drier periods.

\section{DISCUSSION}

Despite the relatively low suspended load in clearwater rivers, the composition of suspended sediments in the Xingu and Tapajós rivers are organic-rich in comparison with white water rivers, showing a marked variation between the dry and wet seasons. Major variations in sediment composition occur due to seasonal changes of hydrology, driving the input of organic and inorganic compounds and regulating primary productivity. The seasonal changes in river discharge controls the relative concentrations of lithophilic elements ( $\mathrm{Ti}, \mathrm{Al}, \mathrm{K}$ ) compared to elements influenced by redox conditions in the water column and riverbed $(\mathrm{P}, \mathrm{Fe}$, $\mathrm{Mn})$. While the uncertainty of organic carbon sources and its stability through time limits its use as proxy for lake productivity or paleo-redox conditions, phosphorous concentration is a useful indicator of paleo-productivity (Engstrom and Wright, 1984; Dean and Gorham, 1998; Boyle, 2001). In order to compensate for fluctuations in allochthonous (terrigenous) inputs of sediments to the ria lake, the $\mathrm{P}$ to Ti ratio was chosen as productivity indicator (Latimer and Filippelli, 2002; Filippelli et al., 2003). Average P/Ti values vary from 4.20 to 0.66 in suspended sediments of the Xingu River during the dry and wet seasons, respectively. The higher values during the dry season are linked to higher primary productivity favored by low water turbidity.

There are significant positive correlations between $\mathrm{Fe}$ and $\mathrm{Ca}(p=0.71, n=198), \mathrm{Fe}$ and $\mathrm{P}(p=0.57, n=198)$ and Fe and TIC $(p=0.97, n=198)$ concentrations in core XC05, which point to biogeochemical controls on Fe and TIC deposition in sediments. The high concentration of $\mathrm{Fe}$ relative to $\mathrm{K}$ in suspended sediments transported during the dry season suggests that assimilation of $\mathrm{Fe}$ in sediments is favored by the increase in organic productivity and oxygenated bottom waters (Table 3 ). Major decreases in TOC concentrations are correlated to peaks of $\mathrm{P} / \mathrm{Ti}, \mathrm{TIC}, \mathrm{Fe}$ and $\mathrm{Mn}$, suggesting lower preservation of organic matter during drier periods (Figure 5). The lack of correlation between TOC and TIC in core XC05 indicates that the shallow bathymetry during drier low-water periods likely decreased calcite solubility, enhanced evaporation and led to the elevated concentration of the carbonate ions (Kelts and Talbot, 1990). Mn and $\mathrm{Fe}$ in sediments are remobilized under reducing conditions and precipitated in the presence of oxygenated waters (Davison, 1993). Lower values of Fe/Mn ratios, proposed by Mackereth (1966) as a redox proxy, are correlated with peaks of $\mathrm{P} / \mathrm{Ti}$, suggesting abrupt shifts in redox conditions during sediment deposition in the Xingu Ria. Peaks of $\mathrm{P} / \mathrm{Ti}$ indicate dominant wetter conditions punctuated by dry events at 3,690-3,650, 3,345-3,335, and 3,235-3,240 years ago (Figure 5). Nutrient-rich and oxygenated waters favor the accumulation of $\mathrm{P}, \mathrm{Fe}$ and $\mathrm{Mn}$ in sediments deposited under drier and low-water level periods. In contrast, TOC is negatively correlated with $\mathrm{P}, \mathrm{Fe}$ and $\mathrm{Mn}$ concentrations due to the lower organic matter preservation under oxic conditions prevailing during drier periods. During the 


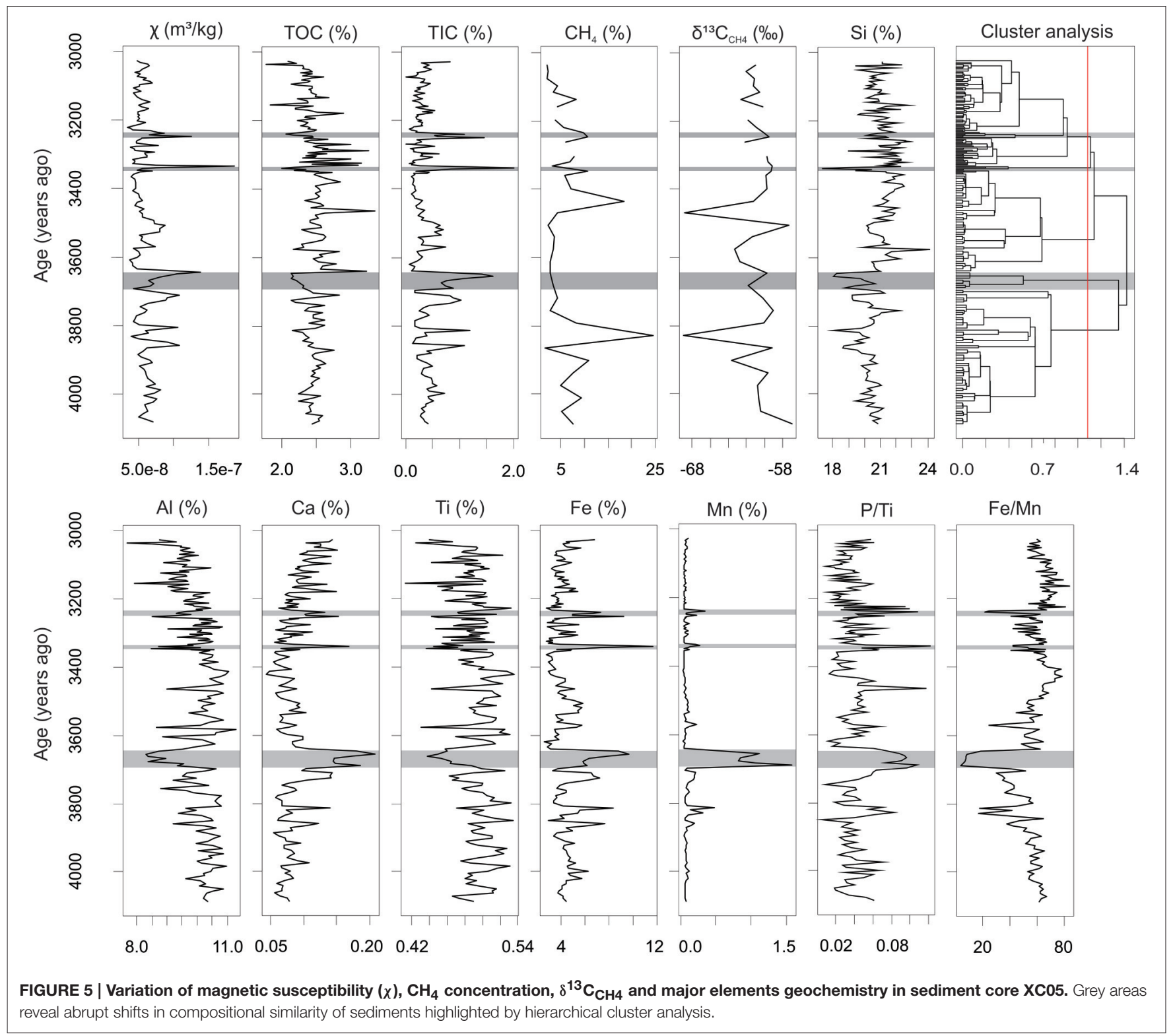

low water season, the shallower water column would be better mixed and the oxic water in contact with the bottom sediment would lead to a faster degradation of the deposited organic matter. Thus, considering the redox and productivity proxies already described, the variation in TOC concentration through time is mainly derived from changes in the water-sediment interface from anoxic/dysoxic (higher TOC) to oxic (lower TOC) conditions that may be related to hydrologic changes in the area drained by the Xingu River.

Fine-grained sediments accumulated in Amazon rias have relatively high concentration of organic carbon (average TOC of $2.45 \%$ ) compared to fine-grained sediments deposited in floodplains under influence of white water rivers such as the Amazon River (0.4-1.4\%; Moreira-Turcq et al., 2004; Aniceto et al., 2014; Moreira et al., 2014). Thus, rias formed in large clearwater rivers such as the Xingu and Tapajós rivers act as hotspots for carbon storage within rivers in the Amazon Basin. These areas are present at least since the middle Holocene, considering the ages obtained for the sediment cores from the Xingu ( $>4,000$ years, this study) and Tapajós rivers $(>9,600$ years, Irion et al., 2006). Stable carbon isotope data $\left(\delta^{13} \mathrm{C}_{\text {org }}\right.$ from -31.04 to $-27.49 \%$ ) indicate a dominant contribution of C3 plants and possibly phytoplankton for the organic particles accumulated in the ria bottom. Palynological data document a large contribution of C3 arboreal plants as major sources of carbon in sediments of the Xingu and Tapajós rias. The labile organic matter derived from phytoplankton may be rapidly consumed and turned into $\mathrm{CO}_{2}$ in the oxic surface sediment layer, while the more recalcitrant terrestrial organic matter accumulates. Also, once buried in the anoxic sediment, the 
autochthonous and labile organic matter may be used to fuel the $\mathrm{CH}_{4}$ production within sediments. This mechanism is in accord with the high $\mathrm{CH}_{4}$ concentrations in pore waters and released to the atmosphere obtained by this work and by Sawakuchi et al. (2014). Despite the large carbon storage, the Xingu and Tapajós rias show the highest fluxes of $\mathrm{CH}_{4}$ to the atmosphere among the major Amazon tributaries (Sawakuchi et al., 2014), suggesting that sedimentary conditions suitable for organic matter preservation favor anoxic conditions in the sediments, where $\mathrm{CH}_{4}$ can be produced and released to the atmosphere. This is supported by the high concentrations (up to $24 \%$ ) of $\mathrm{CH}_{4}$ in sediment pore waters of the Xingu Ria, with $\delta^{13} \mathrm{C}_{\mathrm{CH} 4}$ varying from -70.4 to $-56.9 \%$, suggesting low $\mathrm{CH}_{4}$ oxidation rates. These results indicate that rias in clearwater Amazon rivers are significant organic carbon sinks and sources of $\mathrm{CH}_{4}$ to the atmosphere. They should be considered as distinct environments in the Amazon in order to refine modern carbon balance assessments.

The pollen assemblages show a high diversity of arboreal taxa, pointing to the terra firme and igapó forests as main sources of organic matter within sediments of the Xingu River catchment. Despite the increasing deforestation in the Xingu catchment during the last several decades (Barona et al., 2010), organic carbon stored in riverbed sediments is mainly derived from forest. This could be related to a delay in transfer of the deforestation signal to river sediments, or a dominant input of organic matter from the igapó flooding forest tract along the river channel. The diatom assemblages in riverbed sediments and the sediment core point to a slack water environment in the Xingu Ria since the middle Holocene. Considering that the organic matter pool in sediments of the Xingu and Tapajós rias is mainly terrigenous and derived from forested areas, the input of carbon to the ria sediments is favored during high precipitation episodes while carbon preservation is controlled by duration and frequency of dry periods. Low sedimentation rates combined with well oxygenated waters due to higher primary productivity in the water column favor organic matter degradation in riverbed sediments during dry periods. Despite high rates of organic matter degradation during low-water periods, the higher primary productivity favors the uptake of $\mathrm{CO}_{2}$ and carbon recycling in the water column and riverbed. During high-water phases, the flux of $\mathrm{CO}_{2}$ to the atmosphere increases due to lower primary productivity, while higher sedimentation rates favor organic matter preservation and carbon uptake in sediments. High primary production is the main indicator of $\mathrm{CO}_{2}$ undersaturation observed in large clearwater rivers in the Amazon during the low-water phase (Rasera et al., 2013).

The sediment cores retrieved in the Xingu Ria have ages varying from $3,025 \pm 185$ to $4,086 \pm 159$ years (XC05), from $118 \pm 81$ to $1,251 \pm 211$ years (XC03) and from $2,503 \pm$ 462 to $3,295 \pm 542$ years (XC02). The cores were collected in the deepest part of the river profile and core tops with ages between 3,025 $\pm 185(\mathrm{XC05})$ and 2,503 $\pm 462(\mathrm{XC02})$ years indicate erosional processes and sediment reworking within the ria. The lack of recent deposits indicates that erosion due to channel migration may remobilize sediments in certain portions of the ria. The average sedimentation rate obtained in this study for the Xingu Ria is $0.35 \mathrm{~cm} \mathrm{yr}^{-1}$ since the middle Holocene ( $\sim 4,000$ years). On millennial timescales, sediment deposition rates at different locations are relatively stable. A similar average sedimentation rate of $0.37 \mathrm{~cm} \mathrm{yr}^{-1}$ was also observed for the Tapajós Ria over the last $\sim 11,000$ years Irion et al. (2006). Sedimentation rates from 0.35 to $0.37 \mathrm{~cm} \mathrm{yr}^{-1}$ are relatively high compared to sedimentation rates observed in low latitude lakes, which are typically around 0.05 to $0.25 \mathrm{~cm} \mathrm{yr}^{-1}$ (Cross et al., 2000; Chu et al., 2002; Hodell et al., 2005; Caballero et al., 2006; Conroy et al., 2008; McGlue et al., 2011). Our data show that sedimentation rates varied through time in core $\mathrm{XC05}$. The temporal and spatial variations in sedimentation rates would result from hydrologic changes and sediment reworking within the Ria. The migration of underwater channels and wave action would be the major autogenic processes responsible for sediment remobilization and spatial changes in sedimentation rates. Temporal variations would also be related to precipitation changes affecting sediment supply and accommodation space within the ria. Additional data are required to calculate sedimentation rates with higher temporal resolution and allow a comparison with paleoprecipitation records. This is necessary to constrain the major controls on sedimentation rates and the role of precipitation changes for carbon burial. The TOC concentration in core XC05 varies from 1.77 to 3.35\% (average of $2.45 \%$ ), similar to TOC values measured in bottom sediments collected in the Xingu Ria (average of 2.36\%) (Häggi et al., 2016). Irion et al. (2006) showed TOC values with low variation in the Tapajós Ria, varying from 2.2 to $2.9 \%$ in sediments younger than 7,500 years. The high sedimentation rates would reduce the effectiveness of degradation processes, implying that the Xingu and Tapajós rias are potentially massive carbon sinks on a millennial timescale.

We estimated rates of organic carbon burial in the Xingu and Tapajós rias based on a dry bulk density of $1.3 \mathrm{~g} \mathrm{~cm}^{-3}$ for the bottom ria sediments, average sedimentation rates of $0.35 \mathrm{~cm} \mathrm{yr}^{-1}$ and $0.37 \mathrm{~cm} \mathrm{yr}^{-1}$ (Irion et al., 2006) for the Xingu and Tapajós rias, respectively, and the minimum and maximum TOC concentrations obtained in this work and by Irion et al. (2006). In the Xingu Ria, carbon burial ranges from $84 \mathrm{~g} \mathrm{~m}^{-2} \mathrm{yr}^{-1}$ to $159 \mathrm{~g} \mathrm{~m}^{-2} \mathrm{yr}^{-1}$ (average of $116 \mathrm{~g}$ $\mathrm{m}^{-2} \mathrm{yr}^{-1}$ ) and from 106 to $169 \mathrm{~g} \mathrm{~m}^{-2} \mathrm{yr}^{-1}$ (average of $121 \mathrm{~g}$ $\mathrm{m}^{-2} \mathrm{y}^{-1}$ ) in the Tapajós Ria. Assuming that $75 \%$ (conservative estimate) of the ria surface is covered by fine-grained organicrich sediments (Figure 2), the Xingu Ria buries from $0.08 \mathrm{Tg}$

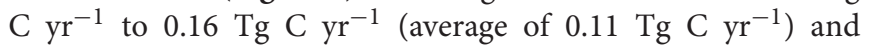

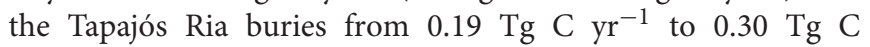

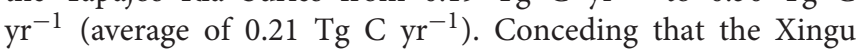
and Tapajós Rias were totally flooded at least since the middle Holocene ( $~ 5,000$ years), around $560 \mathrm{Tg} \mathrm{C}$ and $1050 \mathrm{Tg} \mathrm{C}$ of carbon are stored in sediments of the Xingu and Tapajós rias, respectively.

A rough attempt to estimate the carbon budget of the Xingu Ria is possible considering the average accumulation rate of carbon in sediments of the Xingu Ria of $0.11 \mathrm{Tg} \mathrm{C} \mathrm{yr}^{-1}$ (this

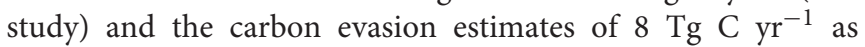
$\mathrm{CO}_{2}$ (Sawakuchi et al., this volume) and $0.053 \mathrm{Tg} \mathrm{C} \mathrm{yr}^{-1}$ as $\mathrm{CH}_{4}$ (Sawakuchi et al., 2014) fluxes to the atmosphere. 
These estimates indicate that despite the significant carbon pool and storage, the Xingu Ria is a net source of carbon to the atmosphere. Furthermore, the Xingu Ria can serve as an analog for sediment accumulation and carbon processing in the reservoirs of the Belo Monte hydropower plant. The multidecadal carbon sedimentation pattern estimated for the Xingu Ria allows projections about sediment accumulation and carbon processing in the Belo Monte reservoirs.

\section{CONCLUSIONS}

The lowermost sectors of the Tapajós and Xingu rivers have lakelike (fluvial ria) sedimentary dynamics due to the impoundment by the Amazon mainstream during the Holocene. This lakelike physiography hinders the transfer of sediments to the Amazon River and induces the accumulation of fine-grained organic-rich sediments derived from upstream areas. Thus, the downstream reaches of these major clearwater rivers are sinks for particulate organic matter chiefly derived from arboreal forest (terra firme and igapó). Wetter periods favor the supply and preservation of forest-derived organic matter in sediments while drier periods increase the organic productivity in the water column and favor degradation of organic matter in riverbed sediments. Microbial consumption of organic matter in the oxic surface layers of the sediment contributes to the anoxic conditions that prevail within sediments, with methanogenesis being an important path for biodegradation of particulate organic matter. During dry and low-water level periods, the flux of $\mathrm{CH}_{4}$ to the atmosphere increases while the $\mathrm{CO}_{2}$ flux decreases due to the higher organic productivity within the water column. Thus, seasonal variations play an important role for carbon dynamics in clearwater rivers. Despite the significant carbon storage that occurs in the Xingu and Tapajós rias at least since the middle Holocene, our carbon balance estimates indicate that Amazon rias would act as source of carbon to the atmosphere. A future drier climate as projected for eastern Amazonia would reduce the carbon sink potential of clearwater rivers and increase the methane flux to the atmosphere.

\section{REFERENCES}

Abril, G., Martinez, J.-M., Artigas, L. F., Moreira-Turcq, P., Benedetti, M. F., Vidal, L., et al. (2014). Amazon River carbon dioxide outgassing fuelled by wetlands. Nature 505, 395-398. doi: 10.1038/nature12797

Algeo, T. J., and Rowe, H. (2012). Paleoceanographic applications of tracemetal concentration data. Chem. Geol. 324-325, 6-18. doi: 10.1016/j.chemgeo. 2011.09.002

Almeida, C. A., de, Coutinho, A. C., Esquerdo, J. C. D. M., Adami, M., Venturieri, A., Diniz, C. G., et al. (2016). High spatial resolution land use and land cover mapping of the Brazilian Legal Amazon in 2008 using Landsat-5/TM and MODIS data. Acta Amaz. 46, 291-302. doi: 10.1590/1809-43922015 05504

ANA (2016). Hidroweb: Sistema de Informações Hidrológicas. Available online at: http://www.snirh.gov.br/hidroweb/ (Accessed October 1, 2016).

Aniceto, K., Moreira-Turcq, P., Cordeiro, R. C., Fraizy, P., Quintana, I., and Turcq, B. (2014). Holocene paleohydrology of Quistococha Lake (Peru) in the upper Amazon Basin: influence on carbon accumulation. Palaeogeogr.

\section{AUTHOR CONTRIBUTIONS}

DJB, AS, and HS were responsible for design of the study and preparation of the manuscript. AS, HS, GH, DJB, and FP organized overall project logistics. DJB and HS executed the sampling and analysis of $\mathrm{CH}_{4}$ in sediment core and performed calculations of carbon balance. FP and AS executed luminescence dating. GH performed magnetic susceptibility analysis. MM, FP, and DJB performed sampling and geochemical analysis of the sediment core. CC, MZ, and ES executed geochemical analysis of suspended and riverbed sediments. TP collaborated with sediment and greenhouse gas sampling and supported local logistics. RS and PO executed palynology analysis. SF and DCB performed diatom analysis. All authors contributed to data interpretation and critically revised the manuscript for final submission.

\section{FUNDING}

This study was funded by FAPESP grants \#2011/06609-1, \#2014/23334-4, \#2016/02656-1 and CAPES grant \#AUXPE $2043 / 2014$.

\section{ACKNOWLEDGMENTS}

We thank Luciana Nogueira and Thays Desiree Mineli for the support with luminescence dating procedures. Bailee Hodelka, Joseph Lucas, and Jason Backus assisted with XRF and coulometry measurements. We also thank the reviewers for constructive criticisms and valuable comments. Open access publication fees were supported by the Gordon and Betty Moore Foundation Marine Microbial Initiative.

\section{SUPPLEMENTARY MATERIAL}

The Supplementary Material for this article can be found online at: http://journal.frontiersin.org/article/10.3389/fmars. 2017.00044/full\#supplementary-material

Palaeoclimatol. Palaeoecol. 415, 165-174. doi: 10.1016/j.palaeo.2014. 08.018

Archer, A. W. (2005). Review of amazonian depositional systems. Fluv. Sedimentol. VII, 17-39. doi: 10.1002/9781444304350.ch2

Armstrong-Altrin, J. S., and Machain-Castillo, M. L. (2016). Mineralogy, geochemistry, and radiocarbon ages of deep sea sediments from the Gulf of Mexico, Mexico. J. South Am. Earth Sci. 71, 182-200. doi: 10.1016/j.jsames.2016.07.010

Aufdenkampe, A. K., Mayorga, E., Raymond, P. A., Melack, J. M., Doney, S. C., Alin, S. R., et al. (2011). Riverine coupling of biogeochemical cycles between land, oceans, and atmosphere. Front. Ecol. Environ. 9, 53-60. doi: 10.1890/100014

Barona, E., Ramankutty, N., Hyman, G., and Coomes, O. T. (2010). The role of pasture and soybean in deforestation of the Brazilian Amazon. Environ. Res. Lett. 5:24002. doi: 10.1088/1748-9326/5/2/024002

Barros, N., Cole, J. J., Tranvik, L. J., Prairie, Y. T., Bastviken, D., Huszar, V. L. M., et al. (2011). Carbon emission from hydroelectric reservoirs linked to reservoir age and latitude. Nat. Geosci. 4, 593-596. doi: 10.1038/ngeo1211 
Battarbee, R. W., Jones, V. J., Flower, R. J., Cameron, N. G., Bennion, H., Carvalho, L., et al. (2001). "Diatoms," in Tracking Environmental Change Using Lake Sediments: Terrestrial, Algal, and Siliceous Indicators, eds J. P. Smol, H. J. B. Birks, W. M. Last, R. S. Bradley, and K. Alverson (Dordrecht: Springer Netherlands), 155-202.

Bertani, T. C., Rossetti, D. F., Hayakawa, E. H., and Cohen, M. C. L. (2014). Understanding Amazonian fluvial rias based on a late pleistocene-holocene analog. Earth Surf. Process. Landforms. 40, 285-292. doi: 10.1002/esp.3629

Bicudo, D. C., Tremarin, P. I., Almeida, P. D., Almeida-Zorzal, S., Wengrat, S., Faustino, S. B., et al. (2016). Taxonomy and ecology of Aulacoseira species (Bacillariophyta) from tropical reservoirs in Brazil. Diatom Research. 31, 199-215. doi: 10.1080/0269249X.2016.1227376

Boës, X., Rydberg, J., Martinez-Cortizas, A., Bindler, R., and Renberg, I. (2011). Evaluation of conservative lithogenic elements ( $\mathrm{Ti}, \mathrm{Zr}, \mathrm{Al}$, and $\mathrm{Rb}$ ) to study anthropogenic element enrichments in lake sediments. J. Paleolimnol. 46, 75-87. doi: 10.1007/s10933-011-9515-z

Böning, P., Cuypers, S., Grunwald, M., Schnetger, B., and Brumsack, H. J. (2005). Geochemical characteristics of Chilean upwelling sediments at $\sim 36^{\circ} \mathrm{S}$. Mar. Geol. 220, 1-21. doi: 10.1016/j.margeo.2005.07.005

Bouchez, J., Beyssac, O., Galy, V., Gaillardet, J., France-Lanord, C., Maurice, L., et al. (2010). Oxidation of petrogenic organic carbon in the Amazon floodplain as a source of atmospheric $\mathrm{CO}_{2}$. Geology 38, 255-258. doi: 10.1130/G30608.1

Bouchez, J., Gaillardet, J., Lupker, M., Louvat, P., France-Lanord, C., Maurice, L., et al. (2012). Floodplains of large rivers: weathering reactors or simple silos? Chem. Geol. 332-333, 166-184. doi: 10.1016/j.chemgeo.2012.09.032

Boyle, J. F. (2001). "Inorganic Geochemical Methods in Palaeolimnology," in Tracking Environmental Change Using Lake Sediments: Physical and Geochemical Methods, eds W. M. Last and J. P. Smol (Dordrecht: Springer Netherlands), 83-141.

Caballero, M., Vázquez, G., Lozano-García, S., Rodríguez, A., Sosa-Nájera, S., RuizFernández, A. C., et al. (2006). Present limnological conditions and recent (ca. $340 \mathrm{yr}$ ) palaeolimnology of a tropical lake in the Sierra de Los Tuxtlas, eastern Mexico. J. Paleolimnol. 35, 83-97. doi: 10.1007/s10933-005-7427-5

California Academy of Sciences (2011). Catalogue of Diatom Names. Compil. by Elisabeth Fourtanier J. Patrick Kociolek. Available online at: http://research.calacademy.org/research/diatoms/names/index.asp (Accessed October 1, 2016).

Chu, G., Liu, J., Sun, Q., Lu, H., Gu, Z., Wang, W., et al. (2002). The "Mediaeval Warm Period" drought recorded in Lake Huguangyan, tropical South China. Holocene 12, 511-516. doi: 10.1191/0959683602hl566ft

Cole, J. J., Prairie, Y. T., Caraco, N. F., McDowell, W. H., Tranvik, L. J., Striegl, R. G., et al. (2007). Plumbing the global carbon cycle: integrating inland waters into the terrestrial carbon budget. Ecosystems 10, 172-185. doi: 10.1007/s10021-006-9013-8

Colinvaux, P. A., De Oliveira, P. E., and Patiño, J. E. M. (1999). Amazon: Pollen Manual and Atlas. Dordrecht: Harwood Academic Publishers.

Conroy, J. L., Overpeck, J. T., Cole, J. E., Shanahan, T. M., and SteinitzKannan, M. (2008). Holocene changes in eastern tropical Pacific climate inferred from a Galápagos lake sediment record. Quat. Sci. Rev. 27, 1166-1180. doi: 10.1016/j.quascirev.2008.02.015

Cross, S. L., Baker, P. A., Seltzer, G. O., Fritz, S. C., and Dunbar, R. B. (2000). A new estimate of the Holocene lowstand level of Lake Titicaca, central Andes, and implications for tropical palaeohydrology. Holocene 10, 21-32. doi: $10.1191 / 095968300671452546$

Davison, W. (1993). Iron and Manganese in lakes. Earth Sci. Rev. 34, 119-163. doi: 10.1016/0012-8252(93)90029-7

Dean, W. E., and Gorham, E. (1998). Magnitude and significance of carbon burial in lakes, reservoirs, and peatlands. Geology 26, 535-538. doi: 10.1130/0091-7613(1998)026<0535:MASOCB > 2.3.CO;2

Dearing, J. A., Dann, R. J. L., Hay, K., Lees, J. A., Loveland, P. J., and Maher, B. A. (1996). Frequency-dependent susceptibility measurements of environmental materials. Geophys J. Int. 12, 228-240. doi: 10.1111/j.1365-246X.1996.tb06366.x

de Faria, F. A. M., Jaramillo, P., Sawakuchi, H. O., Richey, J. E., and Barros, N. (2015). Estimating greenhouse gas emissions from future Amazonian hydroelectric reservoirs. Environ. Res. Lett. 10:124019. doi: 10.1088/17489326/10/12/124019

Denys, L., Muylaert, K., Krammer, K., Joosten, T., Reid, M., and Rioual, P. (2003). Aulacoseira subborealis stat. nov. (Bacillariophyceae): a common but neglected plankton diatom. Nov. Hedwigia 77, 407-427. doi: 10.1127/0029-5035/2003/0077-0407
Engleman, E. E., Jackson, L. L., and Norton, D. R. (1985). Determination of carbonate carbon in geological materials by coulometric titration. Chem. Geol. 53, 125-128. doi: 10.1016/0009-2541(85)90025-7

Engstrom, D. R., and Wright, H. E. (1984). "Chemical stratigraphy of lake sediments as a record of environmental change," in Lake Sediments and Environmental History, eds E. Y. Haworth and J. W. G. Lund (Leicester: University of Leicester Press), 11-67.

EPE/MME (2007). Plano Nacional de Energia 2030. Rio de Janeiro: Empresa de Pesquisa Energética, Ministério de Minas e Energia, 1-408.

Erdtman, G. (1952). Pollen Morphology and Plant Taxonomy. Geol. Föreningen $i$ Stock. Förhandlingar 74, 526-527. doi: 10.1080/11035895209453507

Fearnside, P. M. (2014). Impacts of Brazil's Madeira River Dams: unlearned lessons for hydroelectric development in Amazonia. Environ. Sci. Policy 38, 164-172. doi: 10.1016/j.envsci.2013.11.004

Field, C. B. (1998). Primary production of the biosphere: integrating terrestrial and oceanic components. Science 281, 237-240. doi: 10.1126/science.281.5374.237

Filippelli, G. M., Sierro, F. J., Flores, J. A., Vázquez, A., Utrilla, R., PérezFolgado, M., et al. (2003). A sediment-nutrient-oxygen feedback responsible for productivity variations in Late Miocene sapropel sequences of the western Mediterranean. Palaeogeogr. Palaeoclimatol. Palaeoecol. 190, 335-348. doi: 10.1016/S0031-0182(02)00613-2

Galbraith, R. F., Roberts, R. G., Laslett, G. M., Yoshida, H., Olley, J. M., Galbraith, R. F., et al. (1999). Optical dating of single and multiple grains of quartz from Jinmium rock shelter, Northern Australia: Part I, Experimetal design and statistical models. Archaeometry 41, 339-364. doi: 10.1111/j.1475-4754.1999.tb00987.x

Gourou, P. (1949). Observações geográficas na Amazônia. Rev. Brasil. Geogr. 11, $355-408$.

Grimm, E. (1987). CONISS: a FORTRAN 77 program for stratigraphically constrained cluster analysis by the method of incremental sum of squares. Comput. Geosci. 13, 13-35.

Grimm, E. C. (2011). TILIA software version 1.7.16. Springfield: Illinois State Museum, Research and Collection Center.

Guérin, G., Mercier, N., and Adamiec, G. (2011). Dose-rate conversion factors: update. Ancient TL 29, 5-8.

Häggi, C., Sawakuchi, A. O., Chiessi, C. M., Mulitza, S., Mollenhauer, G., Sawakuchi, H. O., et al. (2016). Origin, transport and deposition of leafwax biomarkers in the Amazon Basin and the adjacent Atlantic. Geochim. Cosmochim. Acta 192, 149-165. doi: 10.1016/j.gca.2016.07.002

Hamilton, P. B., and Siver, P. A. (2010). A Morphological Investigation of Eunotia fennica (Bacillariophyceae) from a freshwater acidic pond in newfoundland, Canada. Proc. Acad. Nat. Sci. Philadelphia 160, 89-98. doi: $10.1635 / 053.160 .0110$

Herron, M. M. (1988). Geochemical classification of terrigenous sands and shales from core or log data. J. Sediment. Res. 58, 820-829.

Hodell, D. A., Brenner, M., and Curtis, J. H. (2005). Terminal Classic drought in the northern Maya lowlands inferred from multiple sediment cores in Lake Chichancanab (Mexico). Quat. Sci. Rev. 24, 1413-1427. doi: 10.1016/j.quascirev.2004.10.013

Irion, G., Bush, M. B., Nunes de Mello, J. A., Stüben, D., Neumann, T., Müller, G., et al. (2006). A multiproxy palaeoecological record of Holocene lake sediments from the Rio Tapajós, eastern Amazonia. Palaeogeogr. Palaeoclimatol. Palaeoecol. 240, 523-535. doi: 10.1016/j.palaeo.2006. 03.005

Irion, G., de Mello, J. A. S. N., Morais, J., Piedade, M. T. F., Junk, W. J., and Garming, L. (2011). "Development of the Amazon Valley During the Middle to Late Quaternary: Sedimentological and Climatological Observations," in Amazonian Floodplain Forests: Ecophysiology, Biodiversity and Sustainable Management, eds J. W. Junk, F. M. T. Piedade, F. Wittmann, J. Schöngart, and P. Parolin (Dordrecht: Springer), 27-42.

Jackson, L. L., and Roof, S. R. (1992). Determination of the forms of carbon in geologic materials. Geostand. Newsl. 16, 317-323. doi: 10.1111/j.1751-908X.1992.tb00495.x

Jarvie, D. M. (1991). "Total organic carbon (TOC) analysis," in Treatise of Petroleum Geology: Handbook of Petroleum Geology, Source and Migration Processes and Evaluation Techniques, ed R. K Merrill (Tulsa, OK, American Association of Petroleum Geologists), 113-118.

Keim, G., Irion, G., Behling, H., Junk, W. J., and Nunes de Mello, J. (1999). "The sediment deposits of lago calado, a ria lake in central amazonia (Brazil), as indicator for postglacial water level rise of the Amazon river," Extended Abstract 
(8 pages) in the Abstract-Volume (CD-Rom) of the International Symposium on "Hydrological and Geochemical Processes in Large Scale River Basins" (Manaus), $1-5$.

Kelts, K., and Talbot, M. (1990). "Lacustrine carbonates as geochemical archives of environmental change and biotic/abiotic interactions," in Large Lakes: Ecological Structure and Function, eds M. M. Tilzer and C. Serruya (Berlin:Springer), 288-315.

Krammer, K. (2000). "The genus Pinnularia," in Diatoms of the European Inland Waters and Comparable Habitats, Vol. 1., ed H. Lange-Bertalot (A.R.G. Gantner Verlag), 1-703.

Latimer, J. C., and Filippelli, G. M. (2002). Eocene to Miocene terrigenous inputs and export production: geochemical evidence from ODP Leg 177, Site 1090. Palaeogeogr. Palaeoclimatol. Palaeoecol. 182, 151-164. doi: 10.1016/S0031-0182(01)00493-X

Latrubesse, E. M., Stevaux, J. C., and Sinha, R. (2005). Tropical rivers. Geomorphology 70, 187-206. doi: 10.1016/j.geomorph.2005.02.005

Mackereth, F. J. H. (1966). Some chemical observations on post-glacial lake sediments. Philos. Trans. R. Soc. B Biol. Sci. 250, 165-213. doi: 10.1098/rstb.1966.0001

McGlue, M. M., Silva, A., Corradini, F. A., Zani, H., Trees, M. A., Ellis, G. S., et al. (2011). Limnogeology in Brazil's "forgotten wilderness": a synthesis from the large floodplain lakes of the Pantanal. J. Paleolimnol. 46, 273-289. doi: 10.1007/s10933-011-9538-5

Meade, R. H., Rayol, J. M., Conceição, S. C., and Natividade, J. R. G. (1991). Backwater effects in the Amazon River Basin of Brazil. Env. Geo. Water Sci. 18, 105-114. doi: 10.1007/BF01704664

Metzeltin, D., and Lange-Bertalot, H. (2007). "Tropical Diatoms of South America II. Special remarks on biogeographic disjunction," in Iconographia Diatomologica, Annotated diatom micrographs, Vol. 18, ed H. Lange-Bertalot (Stuttgart: Koeltz Scientific Books), 1-877.

Moreira, L. S., Moreira-Turcq, P., Kim, J. H., Turcq, B., Cordeiro, R. C., Caquineau, S., et al. (2014). A mineralogical and organic geochemical overview of the effects of Holocene changes in Amazon River flow on three floodplain lakes. Palaeogeogr. Palaeoclimatol. Palaeoecol. 415, 152-164. doi: 10.1016/j.palaeo.2014.03.017

Moreira-Turcq, P., Jouanneau, J. M., Turcq, B., Seyler, P., Weber, O., and Guyot, J. L. (2004). Carbon sedimentation at Lago Grande de Curuai, a floodplain lake in the low Amazon region: insights into sedimentation rates. Palaeogeogr. Palaeoclimatol. Palaeoecol. 214, 27-40. doi: 10.1016/j.palaeo.2004.06.013

Moro, R. S., and Fürstenberger, C. B. (1997). Catálogo dos Principais Parâmetros Ecológicos de Diatomáceas Não-Marinhas. Ponta Grossa: UEPG, 1-282.

Murray, A. S., and Wintle, A. G. (2000). Luminescence dating of quartz using an improved single-aliquot regenerative-dose protocol. Radiat. Meas. 32, 57-73. doi: 10.1016/S1350-4487(99)00253-X

Prescott, J. R., and Hutton, J. T. (1994). Cosmic ray contributions to dose rates for luminescence and ESR dating: large depths and long-term time variations. Radiat. Meas. 23, 497-500. doi: 10.1016/1350-4487(94)90086-8

Rasera, M. F. F. L., Krusche, A. V., Richey, J. E., Ballester, M. V. R., and Victória, R. L. (2013). Spatial and temporal variability of $\mathrm{pCO}_{2}$ and $\mathrm{CO}_{2}$ efflux in seven Amazonian Rivers. Biogeochemistry 116, 241-259. doi: 10.1007/s10533-013-9854-0

R Core Team (2015). R: A Language and Environment for Statistical Computing. Available online at: http://www.r-project.org/.

Reimer, P. J., Bard, E., Bayliss, A., Beck, J. W., Blackwell, P. G., Bronk Ramsey, C., et al. (2013). IntCal13 and Marine13 Radiocarbon Age Calibration Curves 0-50,000 Years cal BP. Radiocarbon 55, 1869-1887. doi: $10.2458 /$ azu_js_rc.55.16947

Richey, J. E., Melack, J. M., Aufdenkampe, A. K., Ballester, V. M., and Hess, L. L. (2002). Outgassing from Amazonian rivers and wetlands as a large tropical source of atmospheric $\mathrm{CO}_{2}$. 6416, 6413-6416. doi: 10.1038/416617a

Ring, E. (1989). The Preperation and Certification of Fourteen South African Silicate Rocks for Use as a Reference Materials. MIntek Report M393.

Roubik, D. W., and Moreno, E. (1991). Pollen and spores of Barro Colorado Island [Panama]. Monogr. Syst. Bot. Missouri Bot. Gard. 36, 1-268.

Round, F. E., Crawford, R. M., and Mann, D. G. (1990). Diatoms: Biology and Morphology of the Genera. Cambridge: Cambridge University Press, 1-747.

Rowe, H., Hughes, N., and Robinson, K. (2012). The quantification and application of handheld energy-dispersive $\mathrm{x}$-ray fluorescence (ED-XRF) in mudrock chemostratigraphy and geochemistry. Chem. Geol. 324, 122-131. doi: 10.1016/j.chemgeo.2011.12.023

Rumrich, U., Lange-Bertalot, H., and Rumrich, M. (2000). Diatoms of the Andes (from Venezuela to Patagonia/Tierra del Fuego). Koenigstein: Koeltz Scientific Books, 1-649.

Sageman, B. B., Murphy, A. E., Werne, J. P., Ver Straeten, C. A., Hollander, D. J., and Lyons, T. W. (2003). A tale of shales: the relative roles of production, decomposition, and dilution in the accumulation of organic-rich strata, Middle-Upper Devonian, Appalachian basin. Chem. Geol. 195, 229-273. doi: 10.1016/S0009-2541(02)00397-2

Sawakuchi, A. O., Hartmann, G. A., Sawakuchi, H. O., Pupim, F. N., Bertassoli, D. J., Parra, M., et al. (2015). The Volta Grande do Xingu: reconstruction of past environments and forecasting of future scenarios of a unique Amazonian fluvial landscape. Sci. Drill. 3, 1-12. doi: 10.5194/sd-20-21-2015

Sawakuchi, H. O., Bastviken, D., Sawakuchi, A. O., Krusche, A. V., Ballester, M. V. R., and Richey, J. E. (2014). Methane emissions from Amazonian Rivers and their contribution to the global methane budget. Glob. Chang. Biol. 20, 2829-2840. doi: $10.1111 / \mathrm{gcb} .12646$

Schulte, S., Mangelsdorf, K., and Rullkötter, J. (2000). Organic matter preservation on the Pakistan continental margin as revealed by biomarker geochemistry. Org. Geochem. 31, 1005-1022. doi: 10.1016/S0146-6380(00)00108-X

Scott, C., and Lyons, T. W. (2012). Contrasting molybdenum cycling and isotopic properties in euxinic versus non-euxinic sediments and sedimentary rocks: refining the paleoproxies. Chem. Geol. 324, 19-27. doi: 10.1016/j.chemgeo.2012.05.012

Sioli, H. (1984). "The Amazon and its main affluents: Hydrography, morphology of the river courses, and river types," in The Amazon: Limnology and Landscape Ecology of a Mighty Tropical River and its Basin, ed H. Sioli (Dordrecht: Springer), 127-165.

Stuiver, M., and Reimer, P. J. (1993). Extended ${ }^{14} \mathrm{C}$ Data base and revised CALIB $3.0{ }^{14} \mathrm{C}$ age calibration program. Radiocarbon 35, 215-230. doi: $10.1017 /$ S0033822200013904

Tranvik, L. J., Downing, J. A., Cotner, J. B., Loiselle, S. A., Striegl, R. G., Ballatore, T. J., et al. (2009). Lakes and reservoirs as regulators of carbon cycling and climate. Limnol. Oceanogr. 54, 2298-2314. doi: 10.4319/lo.2009.54.6_part_2.2298

Tremarin, P. I. , Bertolli, L. M., de Faria, D. M., Costin, J. C., and Ludwig, T. A. V. (2009). Gomphonema Ehrenberg e Gomphosphenia Lange-Bertalot (Bacillariophyceae) do Rio Maurício, Paraná, Brasil. Biota Neotropica 9, 111-130. doi: 10.1590/S1676-06032009000400013

van Dam, H., Mertens, A., and Sinkeldam, J. (1994). A coded checklist and ecological indicator values of freshwater diatoms from the Netherlands. Net. J. Aquat. Ecol. 28, 117-133, doi: 10.1007/bf02334251

Vital, H., and Stattegger, K. (2000). Lowermost Amazon River: evidence of late quaternary sea-level fluctuations in a complex hydrodynamic system. Quat. Int. 72, 53-60. doi: 10.1016/S1040-6182(00)00020-3

Ward, N. D., Krusche, A. V., Sawakuchi, H. O., Brito, D. C., Cunha, A. C., Moura, J. M. S., et al. (2015). The compositional evolution of dissolved and particulate organic matter along the lower Amazon River-Óbidos to the ocean. Mar. Chem. 177, 244-256. doi: 10.1016/j.marchem.2015.06.013

Winemiller, K. O., McIntyre, P. B., Castello, L., Fluet-Chouinard, E., Giarrizzo, T., Nam, S., et al. (2016). Balancing hydropower and biodiversity in the Amazon, Congo, and Mekong. Science 351, 128-129. doi: 10.1126/science.aac7082

Zalat, A., and Vildary, S. S. (2007). Environmental change in Northern Egyptian Delta lakes during the late Holocene, based on diatom analysis. J. Paleolimnol. 37, 273-299. doi: 10.1007/s10933-006-9029-2

Conflict of Interest Statement: The authors declare that the research was conducted in the absence of any commercial or financial relationships that could be construed as a potential conflict of interest.

Copyright (c) 2017 Bertassoli, Sawakuchi, Sawakuchi, Pupim, Hartmann, McGlue, Chiessi, Zabel, Schefuß, Pereira, Santos, Faustino, Oliveira and Bicudo. This is an open-access article distributed under the terms of the Creative Commons Attribution License (CC BY). The use, distribution or reproduction in other forums is permitted, provided the original author(s) or licensor are credited and that the original publication in this journal is cited, in accordance with accepted academic practice. No use, distribution or reproduction is permitted which does not comply with these terms. 